\title{
Diagenetic alteration in low-Mg calcite from macrofossils: a review
}

\author{
Clemens V. ULLMANN ${ }^{1,2}$ and Christoph KORTE ${ }^{1, *}$ \\ 1 University of Copenhagen, Department of Geosciences and Natural Resource Management, Øster Voldgade 10, 1350 \\ Copenhagen, Denmark \\ 2 University of Exeter, Camborne School of Mines, Penryn Campus, Penryn, Cornwall TR10 9FE, U.K.
}

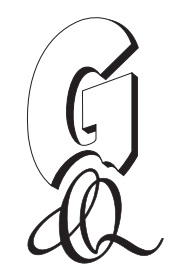

Ullmann, C.V., Korte, C., 2015. Diagenetic alteration in low-Mg calcite from macrofossils: a review. Geological Quarterly, 59 (1): 3-20, doi: 10.7306/gq.1217

The quality of palaeoenvironmental reconstructions based on macrofossil carbonate critically depends on preservation of the shell material because post-depositional processes can modify its structural, chemical and isotopic composition, potentially overprinting or completely erasing palaeoenvironmental information. A suite of methods can be employed to evaluate the impact of diagenetic processes on the primary geochemical signatures of samples. Here we review the benefits and shortcomings of the most commonly employed optical (optical microscopy, cathodoluminescence microscopy, scanning electron microscopy) and chemical (trace element abundances, isotopic ratios) screening techniques used to assess the alteration degree of low-Mg calcite macrofossils and summarize the findings on diagenetic trends observed for elemental and isotopic systems in such materials. For a robust evaluation of the preservation state of biogenic calcite, it is advisable to combine a set of complementary techniques. Absolute limiting values of element and isotope ratios for discarding diagenetically altered materials cannot be universally applied, but should rather be evaluated on a case to case basis. The evaluation can be improved by analyses of diagenetic carbonate and altered fossil materials, which help constraining the diagenetic trajectories in the sampled specimens. Quantification of post-depositional alteration is possible, but in most cases the complexity of diagenetic systems hampers the possibility of retrieving original proxy values for palaeoenvironmental reconstructions from partially altered materials.

Key words: diagenesis, macrofossils, low-Mg calcite, screening methods.

\section{INTRODUCTION}

Calcite fossils have been playing a fundamental role in palaeoenvironmental studies since Urey (1947) proposed that past sea water temperatures can be reconstructed using a carbonate-based oxygen isotope thermometer. Subsequently, publications on palaeothermometry and advances in analytical routines (Urey et al., 1951; Epstein et al., 1951, 1953; Craig, 1957) established the use of calcite macrofossils as a highly important carrier of information for understanding Paleozoic and Mesozoic climate (Bowen, 1961a, b; Fritz, 1964; Longinelli, 1969; Stahl and Jordan, 1969; Tan et al., 1970; Jordan and Stahl, 1970; Tan and Hudson, 1974; Veizer and Fritz, 1976; Buchardt, 1978; Jones et al., 1994; Veizer et al., 1999; Steuber and Veizer, 2002; Prokoph et al., 2008). Refinement of traditional geochemical proxies and frontier work on new palaeoenvironmental tools ensures continued use of macrofossil calcite for reconstructing sea water chemistry and environmental changes in the past (e.g., Finnegan et al., 2011; Korte and

\section{* Corresponding author, e-mail: korte@ign.ku.dk}

Received: October 13, 2014; accepted: January 28, 2015; first published online: January 29, 2015
Hesselbo, 2011; Blättler et al., 2012; Wierzbowski et al., 2012; Price and Passey, 2013; Price et al., 2013; Schobben et al., 2014; Shaviv et al., 2014; Ullmann et al., 2014a). The large size of macrofossils combined with the presence of growth lines also makes them a good target for addressing past seasonal changes in environmental parameters and enables delineation of species-specific geochemical characteristics (e.g., Steuber et al., 2005; Freitas et al., 2006, 2009; Dutton et al., 2007; Ullmann et al., 2010).

However, concerns about the fidelity of geochemical signals measured on fossil materials have been raised since the first palaeotemperature estimates (e.g., Craig, 1954; Compston, 1960), fuelled by analytical results that sometimes predicted unreasonably high palaeosea water temperatures. It is well-established that not all analytical results from macrofossil calcite can be used to reconstruct palaeoenvironmental conditions, because the primary geochemical signals may be altered by post-depositional processes (e.g., Longinelli, 1969; Brand and Veizer, 1980, 1981; Al-Aasm and Veizer, 1986a, b; Ullmann et al., 2013a). The geochemical signatures of biogenic carbonate can also deviate from the sea water signal because of metabolically driven geochemical disequilibria (so-called vital effects), which are not discussed in the present review. The reader is referred to Wefer and Berger (1991), Parkinson et al. (2005), Yamamoto et al. (2011) and references therein for detailed appraisals of such effects. 
In order to address potential post-depositional impacts on geochemical signatures of biogenic calcite, dedicated studies have been conducted to understand diagenetically-induced chemical and structural changes on macrofossils (e.g., Brand and Veizer, 1980, 1981; Veizer, 1983a; Al-Aasm and Veizer, 1986a, b; Brand, 1991; Ullmann et al., 2013a). Furthermore, extensive databases with chemical compositions of modern analogues have been assembled (e.g., Morrison and Brand, 1986; Brand et al., 2003). In combination with knowledge of geochemical trends of diagenesis, these databases provide auxiliary information for establishing quality markers of sample preservation state. It has been proposed that "low-Mg-calcite" (LMC) fossils, i.e. calcite fossils with $\mathrm{Mg} / \mathrm{Ca}$ ratios < 40-50 mmol/mol (Veizer, 1983a; Morrison and Brand, 1986), are one of the best substrates to obtain geochemical signals of past environments because this type of carbonate is relatively resistant to diagenesis (Veizer, 1983a, b; Marshall, 1992). In addition, the alteration degree of LMC fossils can be identified by different techniques, such as binocular microscopy, scanning electron microscopy (SEM), cathodoluminescence microscopy and elemental distribution (Popp et al., 1986; Veizer et al., 1986; Grossmann et al., 1996; Bruckschen et al., 1999; Mii et al., 1999). Quality assessments for bulk rock carbonates, biogenic aragonite and high magnesium calcite, as well as micro- and nannofossils partially overlap with these routines, but here only reference is made to diagenesis in biogenic LMC. The specific strengths and caveats for the techniques identifying alteration in carbonate are discussed below.

\section{OPTICAL SCREENING TECHNIQUES}

Biogenic calcite shows a range of morphologies which differ considerably from inorganic precipitates, because the bio-mineralisation process is steered towards the construction of a stabilizing and securing shell. During this process, crystal lattice and habit can be modified (Pokroy et al., 2006) with the result that the negative effects of the perfect cleavages (leading to critical failure of the shell at impact) are counteracted. The shell needs to withstand physical stress, but it also has to be shaped according to the organism's body form and living style. Thus, it needs to be flexible to some degree, and has to be constructed in an energy-efficient way. The sum of these demands leads to elaborately shaped, hierarchically organized bio-minerals exhibiting an intimate association with organic macromolecules (Barbin, 2000; Weiner and Dove, 2003; Addadi et al., 2006; Furuhashi et al., 2009).

These elaborate shapes are bound to degrade to more simple angular outlines of inorganic calcite when approaching thermodynamic equilibrium. It is this particular path of degradation of fossil calcite during diagenesis that can be tracked with optical techniques.

\section{MACROSCOPIC AND BINOCULAR MICROSCOPE INSPECTIONS}

A first efficient test to evaluate fossil preservation can already be done by inspecting the shell material with a hand lens and/or binocular microscope (Fig. 1). Macroscopic evidence of silicification can be identified by concentric rings on shell surfaces or by residual fragments left after briefly attacking the fossils calcite with acid (Fig. 1A). Shell ultrastructure in the silicified parts is usually lost, whereas surface morphologies might be preserved (Fig. 1B). Recrystallisation and cementation can also erase the shell ultrastructure (Fig. 1C, D, F), commonly associated with a loss of transparency and development of grainy surfaces of shell layers as well as fractures (Fig. 1C). Primary porosity of shells, such as punctae of punctate brachiopods (Fig. 1D), as well as secondary cavities induced e.g., by borings (Fig. 1A, E) often house secondarily-precipitated (carbonate) phases. In addition, alteration and secondary precipitates are concentrated along fracture surfaces; often observed in belemnite rostra (Fig. 1F). The microscopic inspection also allows for the identification of contamination by traces of attached sediment.

\section{SCANNING ELECTRON MICROSCOPY}

The high-magnification capabilities of scanning electron microscopy have been successfully employed to image subtle post-depositional changes and diagenetic degradation of shell ultrastructures (e.g., Brand, 1989; Sælen, 1989; Korte and Hesselbo, 2011; Jelby et al., 2014; Fig. 2). Smooth surfaces of crystal fibres (Fig. 2B-D) in fossil shells are comparable to those of modern, unaltered counterparts (Fig. 2A) and are therefore indicative of good preservation. The fibres of biogenic calcite may show surficial expressions of dissolution (Fig. 2E, F), and, especially in brachiopods, dissolution pits which often follow the crystal orientation (Fig. 2E). Cementation, occurring often in brachiopod punctae (Fig. 2B), can be successfully documented with the SEM. Recrystallisation leads to destruction of the original crystal fibre morphologies (Fig. 2G-I) and in later stages the crystal habit of abiogenic calcite can be observed rather than the crystal fibres of biominerals (Fig. 2G). In addition, deformation of shell fibres, planar recrystallisation features, and angular fracture planes (Fig. 2H) occur in altered shells. When recrystallisation commences, the general shell morphology might remain intact, but crystal structures of single fibres start to rearrange, leading to the loss of the smooth surfaces (Fig. 2I).

SEM screening is primarily a qualitative assessment of surface features and crystal fracture patterns. Therefore, SEM imagery alone cannot be used to evaluate to which degree geochemical proxies deviate from primary values due to partial diagenetic resetting (Rush and Chafetz, 1990; Lu, 2008). SEM investigations, however, can be supplemented by other analytical routines, probing the crystal lattice structure and orientation of biogenic calcite. Anisotropic extension of the a- and c- axes of well-preserved mollusc calcite can be ascertained using X-ray diffraction (Pokroy, 2006). The preservation of the lattice structure of single crystal fibres can be controlled using electron backscatter diffractometry (EBSD; e.g., Cusack and Freer, 2008; Pérez-Huerta and Cusack, 2009). It is also possible to establish preservation indices on the basis of SEM imagery that can be compared to geochemical data generated for the fossil specimens (Cochran et al., 2010; Jelby et al., 2014). In many instances, only a limited number of representative sample fragments can be checked using the SEM technique rather than the complete set of aliquots which are taken to delineate geochemical trends. It therefore needs to be kept in mind that small-scale heterogeneity of the fossil preservation might partially bias SEM based preservation assessments. SEM observations, however, provide essential information on the general preservation of fossil materials originating from individual successions and different facies types.

\section{CATHODOLUMINESCENCE MICROSCOPY}

Cathodoluminescence $(\mathrm{CL})$ microscopy is used to spatially resolve the preservation degree of fossil shells (e.g., Machel, 

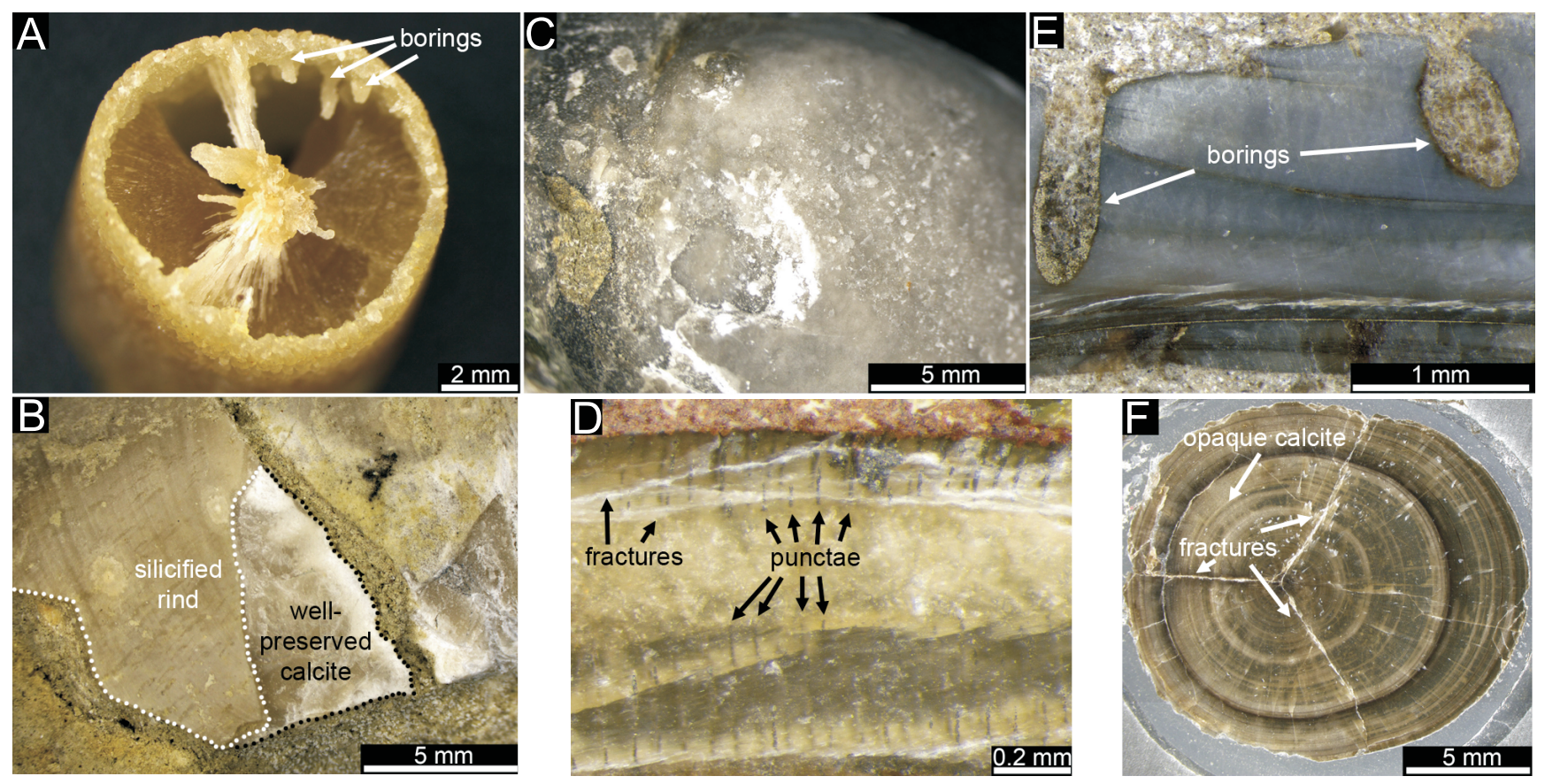

Fig. 1. Examples of diagenetically altered macrofossils

A - partly silicified Cretaceous belemnite rostrum; the silicate component has a grainy texture towards the outside of the rostrum and traces the previous calcite structure in the inside, filling borings (upper right); silica was precipitated along crystal surfaces and the central apical zone; the amber-coloured calcite of the rostrum appears to be well-preserved; B - partly silicified Cretaceous bivalve; the fractured specimen has a silicified rind below which well-preserved calcitic shell layers (centre and right) are exposed; $\mathbf{C}$ - Early Jurassic bivalve; the shell has a light, opaque colour and a grainy texture, both indicative of post-depositional alteration; D - thick section through a Middle Jurassic punctate brachiopod; the punctae are filled with a secondary, opaque phase; the outermost layers (upper part) show some fractures, the central part shows decoloration and loss of primary shell structure, whereas the inner part of the shell (lower part of the photo) does not show visible signs of re-crystallisation; $\mathbf{E}$ - thick section through an Early Jurassic bivalve; the shell shows little sign of alteration with primary layering and violet hue being preserved, but has been abraded by boring organisms (top left and top right); $\mathbf{F}$ - thick section through an Early Jurassic belemnite rostrum; the ventral part (left side) shows a larger fraction of opaque calcite, indicative of alteration, while the dorsal part (right side) shows mostly translucent calcite pointing to good preservation; three fractures tracing the two dorsal as well as the ventral groove of the specimen run through the rostrum and meet at the apical zone

1985; Popp et al., 1986; Sælen, 1989; Machel and Burton, 1991; Grossman et al., 1993; Savard et al., 1995; Mii et al., 1997; Barbin, 2000; Rosales et al., 2001; Wierzbowski et al., 2009; Benito and Reolid, 2012). Certain trace elements - especially $\mathrm{Mn}$ incorporated into calcite during alteration (Machel, 1985; Barnaby and Rimstidt, 1989; Savard et al., 1995; Barbin, 2000) - emit characteristic dull to bright radiation during cathodic excitation of the shell calcite and induce a typical orange colour (Fig. 3) indicative of diagenetic alteration. This technique visualizes partly altered materials, usually following cracks, shell surfaces, punctae and/or growth bands (Fig. 3). CL microscopy operates with the assumption that this characteristic luminosity is absent in well-preserved biogenic calcite showing a weak blue, "intrinsic" luminosity (Fig. 3A, blue parts), which is related to structural defects in the calcite crystal lattice (Barbin, 2000). This mapping by CL microscopy can be of considerable benefit for understanding fossil preservation, because the textures and intensity of the luminescence (Fig. 3A, C, E, F) may be taken into account and related to preservation gradients in single specimens. Heterogeneous preservation is clearly evident in high resolution screenings (CL, elements, isotopes) of belemnites (Ullmann et al., 2013a) and also indicated by isotopic differences between well-preserved shell material and cements (Fig. 3A-D). CL microscopy, however, also has pitfalls:

1 Non-luminescent materials might be altered (e.g., Rush and Chafetz, 1990; Barbin, 2000). This is because the lack of luminescence can be induced by other diagene- tically incorporated elements (mainly Fe) suppressing the emission of the characteristic orange light from Mn-enriched material. The $\mathrm{Mn} / \mathrm{Fe}$ ratio therefore has a strong influence on the luminescence intensity (Frank et al., 1982; Barbin, 2000). Brightly luminescent calcite cements are confined to areas where pore waters meet certain Eh and $\mathrm{pH}$ conditions that lead to Mn enrichments, while low Fe concentrations in the liquid are maintained (Machel, 1985; Barnaby and Rimstidt, 1989). The problem of suppressed luminescence due to Fe-enrichments can be partially overcome using staining techniques (potassium ferricyanide $\mathrm{K}_{3}\left[\mathrm{Fe}(\mathrm{CN})_{6}\right]$; Dickson, 1966; Popp et al., 1986).

2 Well-preserved and even modern shells can show bright luminescence that may be related to a variety of environmental controls (Barbin, 2000 and references therein). Therefore, CL characterization should not be used as the sole technique for determining the preservation state of macrofossil calcite.

\section{SAMPLE EXTRACTION}

The first step of fossil preparation is sometimes combined with a step of chemical corrosion of the shell surfaces or fossil fragments using dilute acids, e.g. $\mathrm{HCl}$. This surface dissolution is applied to chemically remove traces of diagenetic carbonates and to clean the surface before sampling (Jones et al., 1994; 

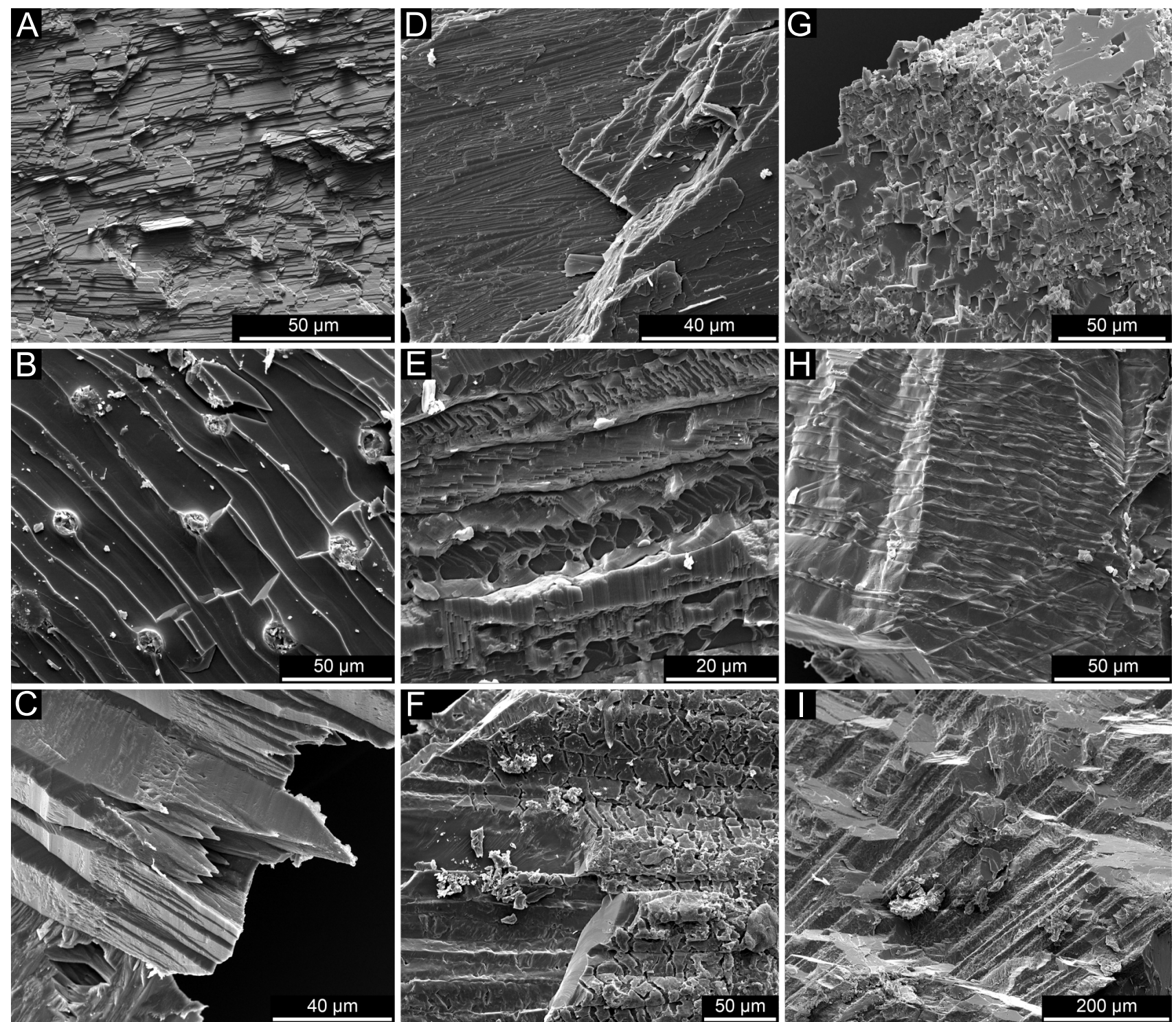

Fig. 2. SEM photos of macrofossils

A - foliate layers of modern oyster (Crassostrea gigas) from the List Basin (North Sea, Germany); the hierarchical nature of the shell structure (layers, bundles and single fibres) is evident; B - secondary fibrous layers of Jurassic punctate brachiopod from New Zealand; the crystal fibres are smooth, indicating good shell preservation, but the punctae are filled with secondary mineral phases; $\mathbf{C}$ - well-preserved crystal fibres of Late Jurassic belemnite rostrum from New Zealand; single crystals have obelisk-like morphologies, with the tips pointing towards the central apical line; rhomb-shaped voids in the calcite (lower left) are arranged in concentric bands in the rostrum; D - Early Jurassic bivalve fragment from Yorkshire (United Kingdom) showing good shell preservation and a similar hierarchical stacking of crystal fibres as modern shells; E - partially dissolved secondary foliate layers of a Late Triassic brachiopod from New Zealand; the orientation and form of the dissolution pits seem to be controlled by the crystal orientation of the fibres; $\mathbf{F}$ - fragment of a Late Jurassic belemnite rostrum from New Zealand showing features of partial dissolution; dissolution follows a chicken wire pattern in this instance and has progressed further in the fibres to the upper right; $\mathbf{G}$ - nearly completely recrystallised Late Jurassic bivalve shell from New Zealand; the original shell structure is pervasively overprinted by rhombic calcite crystals; $\mathbf{H}$ - recrystallised Triassic brachiopod fragment from New Zealand; the shell fibres lose the smooth appearance and planar, parallel recrystallisation features as well as fractures can be observed; I- partially recrystallised Late Jurassic belemnite fragment from New Zealand; the crystals have attained a rough surface and the onset of a structural rearrangement is evident through small-angle steps on fracture surfaces

McArthur et al., 2007; Jelby et al., 2014). This technique cannot be recommended for universal use because it has been found that the acid can preferentially attack well-preserved fossil material, leaving behind a residuum with increased altered calcite fraction (Podlaha et al., 1998). Such preferential dissolution of biogenic calcite can be explained by a significantly higher density of crystal defects and the characteristic shapes of biogenic carbonates which make them less thermodynamically stable than inorganic calcite (Plummer and Busenberg, 1982; Busenberg and Plummer, 1989). Due to these imperfections, the solu- bility of biogenic carbonate tends to be higher than abiogenic precipitates with equal magnesium concentrations (Fig. 4). Because acid attacks also result in degradation of shell surfaces, a subsequent optical screening of the texture would be difficult, but colours and opaqueness can still be assessed.

Physical abrasion itself, using drilling or scratching devices, also enables an assessment of the preservation state. (1) Pristine shell material breaks easily along biogenically precipitated crystals, while re-crystallised or silicified fossils can be hard. (2) Drilling and scratching of well-preserved materials normally 

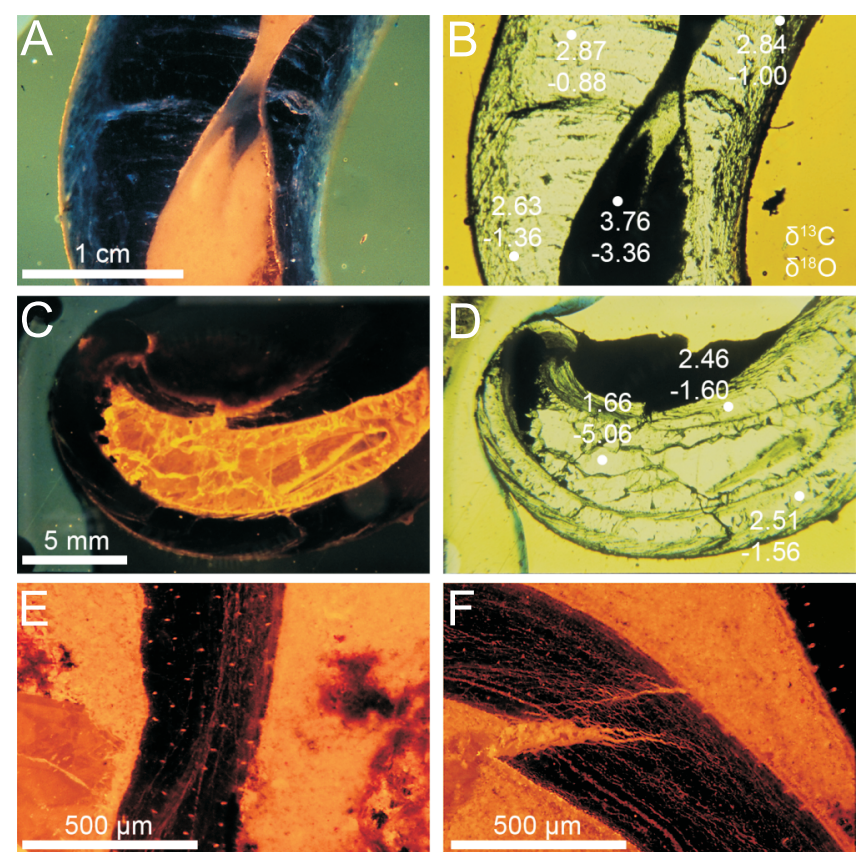

Fig. 3. Cathodoluminescence in fossil calcite

A - Late Triassic brachiopod from the Southern European Alps showing intrinsic luminescence; the inner and outer shell surfaces and micritic cement exhibit orange luminescence; $\mathbf{B}$ - the same specimen $(A)$ in transmitted light; carbon (top) and oxygen isotope values (bottom) for three shell samples and one cement sample; C Late Triassic, mostly non-luminescent brachiopod from the Southern Alps with sparry cement showing orange luminescence; D - the same specimen (C) in transmitted light; carbon (top) and oxygen isotope values (bottom) for two shell samples and one cement sample; E - partly luminescent Middle Triassic brachiopod shell from Germany with brightly luminescent punctae; F - partly luminescent Middle Triassic brachiopod shell from Germany; luminescence in the shell follows bands and is not as bright as in the matrix

yields white powders, whereas those from altered samples can be yellowish to brownish, e.g. indicating the presence of impurities such as silica, oxides and hydroxides.

\section{SAMPLE AREAS TO BE AVOIDED}

Material from the inner and outer surface of bivalve and brachiopod shells should be avoided during sampling due to their higher sensitivity to diagenetic alteration and proximity to the sediment and diagenetic fluid. Furthermore it is observed in belemnites that the rims, the apical zone and areas exhibiting decoloured calcites, are frequently diagenetically altered (Podlaha et al., 1998; McArthur et al., 2000, 2007; Ullmann et al., 2013a). Alteration is most prominent where cracks, cavities and crystal surfaces provide enough permeability for fluid percolation. All these areas should be avoided when sampling for palaeoenvironmental reconstruction. Instead, the intermediate shell layers of bivalves and brachiopods, and the growth bands mid-way between the rim and apical zone in the case of belemnites are most likely to yield well-preserved sample material.

\section{CHEMICAL SCREENING TECHNIQUES}

The bio-mineralisation process not only dictates the shape of the calcite crystals in the biogenic hard parts, but also has

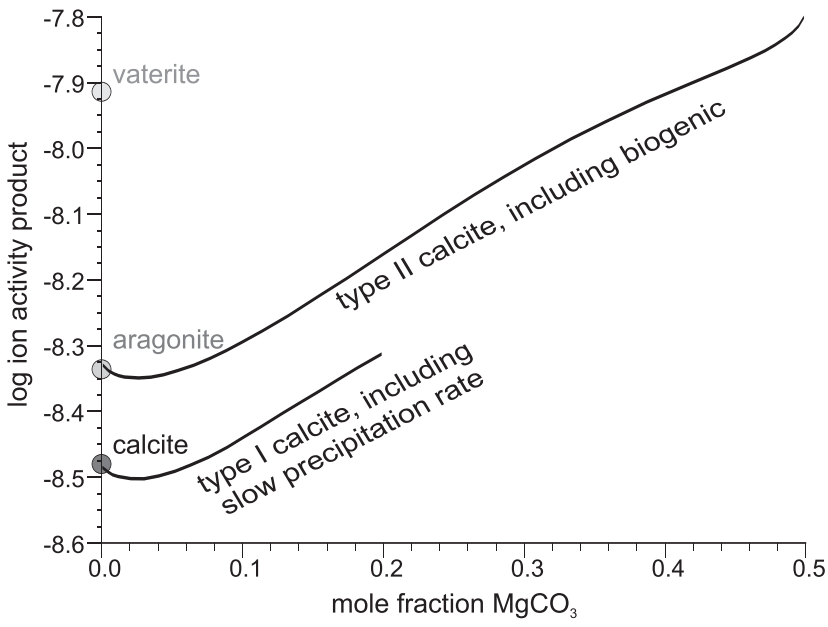

Fig. 4. Ion activity product of different calcium carbonate polymorphs and calcite, depending on its molar magnesium fraction

For pure abiogenic precipitates of $\mathrm{CaCO}_{3}$ phases, calcite is more stable than aragonite and vaterite. Beyond a stability optimum at low $\mathrm{Mg}$ concentrations, the calcite stability decreases with increasing $\mathrm{Mg}$ contents. A significant difference is observed between slowly precipitating abiogenic calcite (type I calcite) and biogenic calcite (type II calcite). Biogenic calcite is significantly less stable than type I calcite with equivalent $\mathrm{Mg}$ concentration, inferring that secondary cements might be more stable than the original LMC. Data from Plummer and Busenberg (1982) and Busenberg and Plummer (1989)

profound effects on the uptake of minor and trace elements into the crystal lattice. Element/Ca ratios in biogenic calcite almost always clearly deviate from those of diagenetic carbonates (e.g., Brand and Veizer, 1980; Veizer, 1983a, b), making measurements of element/Ca ratios a powerful tool for evaluating fossil preservation (Fig. 5). Comparisons of analytical results of fossil and modern shells are also often employed as additional means for assessing sample preservation (e.g., Veizer et al., 1999; Shields et al., 2003; Immenhauser et al., 2005; Armendáriz et al., 2012).

\section{MANGANESE IN CALCITE FOSSILS}

Oxic conditions are essential for large, shell-forming metazoans. In oxygenated sea water, manganese concentrations are extremely low, because $\mathrm{Mn}$ is precipitated in its oxidized form via catalytic processes (Crerar and Barnes, 1974) and thereby removed from the water column. Consequently, the shell calcite of most LMC macrofossils in its original form contains only trace amounts of Mn. Manganese, is soluble as reduced $\mathrm{Mn}$ (II) in poorly oxygenated to anoxic pore waters (Crerar and Barnes, 1974; Algeo and Maynard, 2004) and can be incorporated into carbonate phases (Thomson et al., 1986) because it is a compatible element in calcite as Mn(II) (Dromgoole and Walter, 1990; Rimstidt et al., 1998; Figs. 6 and 7). Concentrations of Mn in calcite can therefore be used to assess the preservation state of fossils (e.g., Veizer, 1974; Korte et al., 2003).

Operational upper limits for $\mathrm{Mn} / \mathrm{Ca}$ ratios in LMC macrofossils are used to best exclude diagenetically altered samples from palaeoenvironmental reconstructions. These limits differ, depending on fossil type, sedimentary setting and between researchers (Table 1). Most calcifiers form shell material with very low Mn concentrations, but there are instances in which primary enrichments occur. Some of these enrichments considerably exceed the assumed upper limits of unaltered material (Ta- 


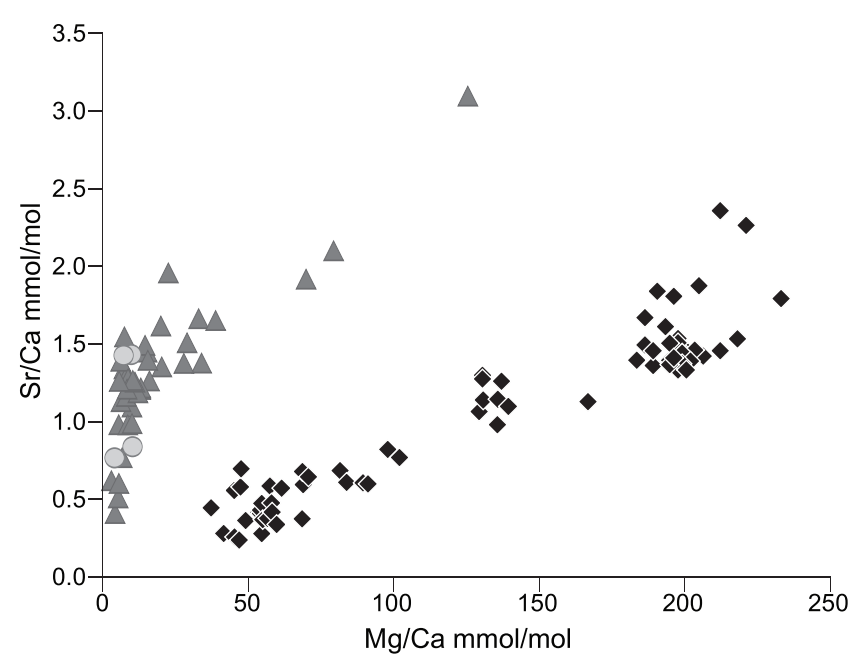

Fig. 5. Cross plot of $\mathrm{Mg} / \mathrm{Ca}$ and $\mathrm{Sr} / \mathrm{Ca}$ ratios in biogenic and abiogenic calcite

An offset towards higher Sr/Ca ratios in biogenic calcite are observed. Brachiopod data (triangles) are averaged for single species and taken from Brand et al. (2003). Bivalve data (circles) are species averages for Pecten maximus and Mytilus edulis (Freitas et al., 2009) and averages for foliate layers and chalky substance of Crassostrea gigas (Ullmann et al., 2013b). Data for abiogenic calcite (diamonds) is from Carpenter et al. (1991) and Major and Wilber (1991)

ble 1). It has been reported that the primary Mn uptake in modern oysters from Portugal is higher (averages of $\mathrm{Mn} / \mathrm{Ca}$ up to $\sim 0.1 \mathrm{mmol} / \mathrm{mol}$ ) the closer to the shore the oyster bank is situated (Almeida et al., 1998). Similar $\mathrm{Mn} / \mathrm{Ca}$ ratios (up to $0.12 \mathrm{mmol} / \mathrm{mol}$ ) have been observed in modern Pecten maximus from the United Kingdom (Freitas et al., 2006), while in modern Mytilus edulis from the Netherlands, Mn/Ca ratios even reach $0.4 \mathrm{mmol} / \mathrm{mol}$ (Vander Putten et al., 2000). Vander Putten et al. (2000) link Mn enrichments in shell calcite to increased manganese availability in the water due to poor oxygenation of ambient water $\mathrm{O}_{2}$. Brand et al. (2003) report ratios of up to $0.64 \mathrm{mmol} / \mathrm{mol}$ for the modern inarticulated brachiopod Neocrania anomala in Portugal. The above findings suggest that molluscs that are able to (temporarily) tolerate low oxygen conditions can show primary Mn enrichments in their shells (a strong additional influence of the animal's metabolism, however, is also evident; Freitas et al., 2006).

Data suggesting primary manganese uptake and incorporation into shell calcite have also been observed for fossil molluscs (Korte and Hesselbo, 2011). In the latter study, high $\mathrm{Mn} / \mathrm{Ca}$ ratios were reported for texturally pristine Early Jurassic pectenids and pinnids, which have similar $\delta^{13} \mathrm{C}$ and $\delta^{18} \mathrm{O}$ values as shells of other coeval fossils (belemnites, oysters, brachiopods) with lower $\mathrm{Mn} / \mathrm{Ca}$ ratios. The similar isotope values and the textural preservation thus suggest that the Early Jurassic pectenids and pinnids were not significantly altered and that primary enrichment of $\mathrm{Mn}$ took place.

The potential for Mn enrichment in altered macrofossil materials depends on the availability and solubility of $\mathrm{Mn}$ in the diagenetic environment. $\mathrm{Mn}$ incorporated into diagenetic calcite is derived from Mn-bearing phases in the sediments, whose abundance can be spatially very variable and depends on the geological context. Furthermore, the redox state of the diagenetic fluid might be highly variable in space and time (Ullmann et al., 2013a, 2014b; Table 2), which in turn will affect the $\mathrm{Mn}$ concentrations within the fluid. In order to generate a strong enrichment of $\mathrm{Mn}$ in secondary calcite, a large supply of $\mathrm{Mn}$ to the diagenetic fluid is required (Veizer, 1983a, b). In closed systems the efficient removal of $\mathrm{Mn}$ from the fluid by incorporation of $\mathrm{Mn}$ (II) into diagenetic calcite progressively depletes the fluid in Mn, leading to higher concentrations of $\mathrm{Mn}$ in early diagenetic precipitates and progressively lower values in calcite formed later (Fig. 7). Altered fossil calcite will therefore always
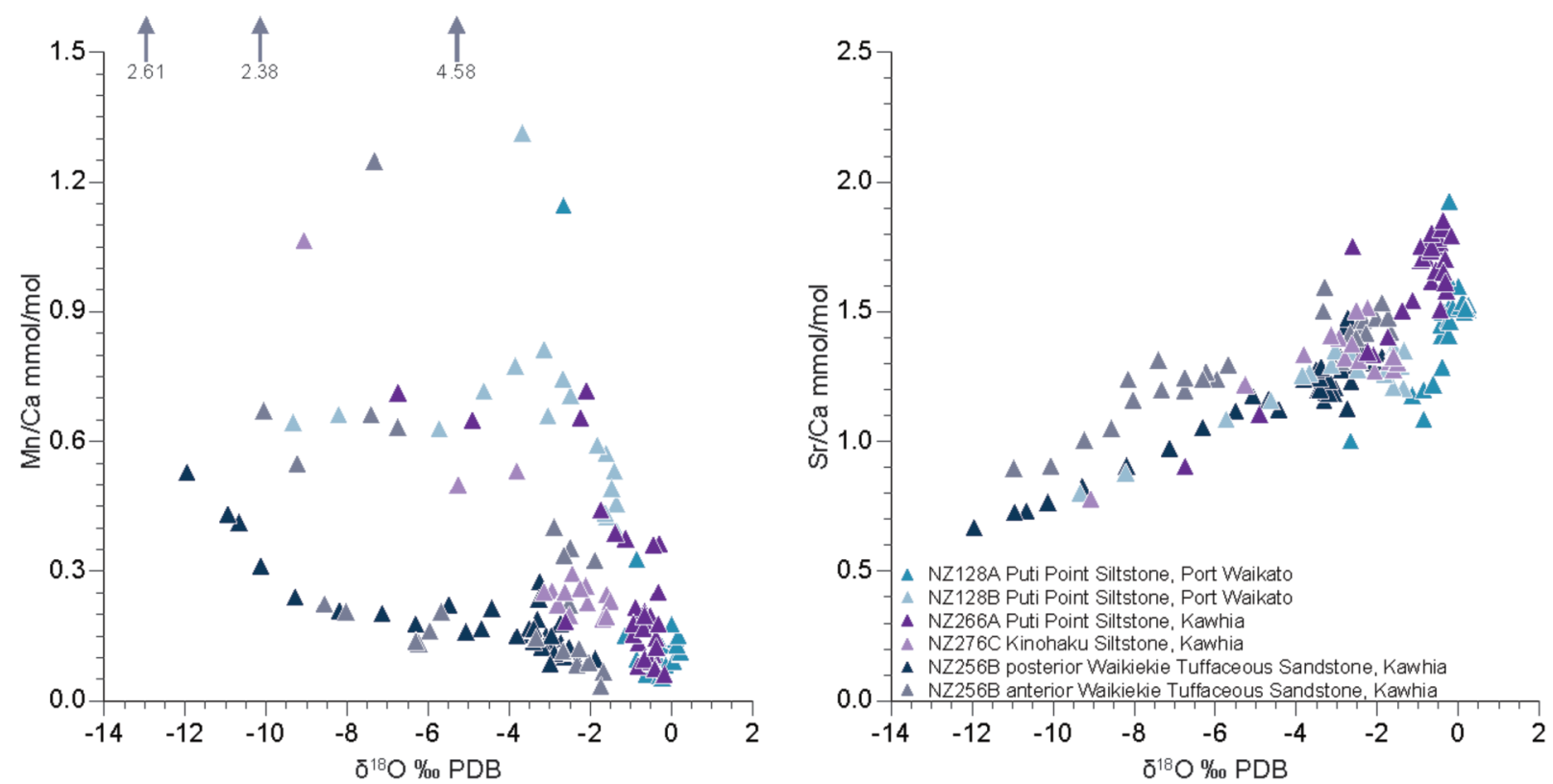

Fig. 6. $\mathrm{Mn} / \mathrm{Ca}$ ratios and $\mathrm{Sr} / \mathrm{Ca}$ ratios of five Late Jurassic belemnite rostra from New Zealand plotted against $\delta^{18} \mathrm{O}$ values

Clear tendencies of $\mathrm{Mn}$ enrichment and $\mathrm{Sr}$ depletion in conjunction with ${ }^{18} \mathrm{O}$-depletion are observed; data scatter is significantly increased when comparing multiple rostra; data for specimen NZ256B are from Ullmann et al. (2013a) 
carry the potentially dynamic fingerprints of the diagenetic setting, which is defined by regional and local characteristics.

As a general summary, $\mathrm{Mn} / \mathrm{Ca}$ ratios are very useful for a (semi-)quantitative evaluation of the preservation state of fossil calcite. A global, constant $\mathrm{Mn} / \mathrm{Ca}$ limit for identifying altered calcite fossils, however, cannot be universally employed. Potential Mn enrichments associated with diagenetic alteration must be evaluated for all fossil groups and geological settings and it is recommended here to use this criterion along with information from other screening techniques.

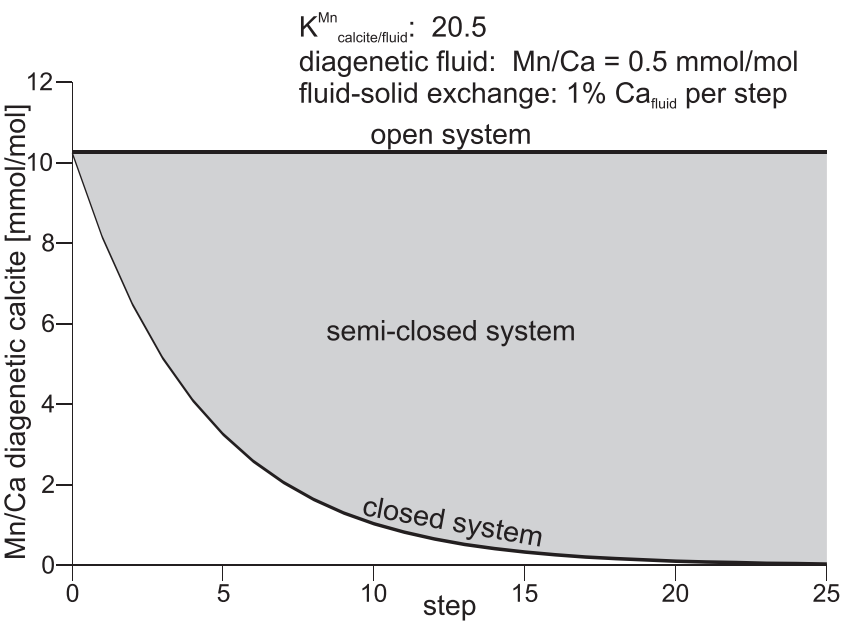

\section{IRON IN CALCITE FOSSILS}

Fe shows a chemical behaviour similar to $\mathrm{Mn}$ in sea water. In oxic sea water, $\mathrm{Fe}$ is complexed as $\mathrm{Fe}(\mathrm{OH})_{3}^{0}$ and precipitates in the form of Fe oxides and hydroxides (Glasby and Schulz, 1999), efficiently removing dissolved Fe from the water column. Under reducing conditions and at reduced $\mathrm{pH}$, however, Fe becomes soluble as Fe(II) (Glasby and Schulz, 1999), which can be diagenetically incorporated into biogenic calcite (e.g., Brand and Veizer, 1980). Upper limits of Fe/Ca ratios can therefore guide in

Fig. 7. Conceptual model for the stepwise evolution of the $\mathrm{Mn} / \mathrm{Ca}$ ratio in calcite cements in open, semi-closed and closed diagenetic systems

The model assumes a partition coefficient of 20.5 for Mn (Rimstidt et al., 1998) and a diagenetic fluid with an initial $\mathrm{Mn} / \mathrm{Ca}$ ratio of $0.5 \mathrm{mmol} / \mathrm{mol}$. At each step $1 \%$ of the Ca inventory of the fluid is precipitated as cement and replaced by an equivalent amount of Ca derived from dissolution of $\mathrm{Mn}$-free primary calcite. In an open system, the diagenetic fluid is advected away and is replaced by a fluid with the initial composition, so that the $\mathrm{Mn} / \mathrm{Ca}$ ratio of calcite cements is only determined by the initial composition of the fluid and the partition coefficient of $\mathrm{Mn}$. In a closed system, $\mathrm{Mn}$ is rapidly removed from the initial fluid during cement formation and during ongoing fluid movement cements with progressively lower Mn enrichment are formed

Upper limits for $\mathrm{Mn} / \mathrm{Ca}$ ratios in well-preserved LMC macrofossils

\begin{tabular}{|c|c|c|c|c|}
\hline Material & Age & Area & $\begin{array}{c}\mathrm{Mn} / \mathrm{Ca} \text { limit } \\
\mathrm{mmol} / \mathrm{mol}\end{array}$ & Source \\
\hline Belemnites & Cretaceous & UK, Germany & 0.09 & Malkoc and Mutterlose (2010) \\
\hline Belemnites & Cretaceous & Germany & 0.09 & Mutterlose et al. (2010) \\
\hline Belemnites & Cretaceous & Europe & 0.18 & Voigt et al. (2003) \\
\hline Belemnites & Cretaceous & Hungary & 0.18 & Price et al. (2011) \\
\hline Belemnites & Jurassic & Spain & 0.03 & Benito and Reolid (2012) \\
\hline Belemnites & Jurassic & UK & 0.06 & Jones et al. (1994) \\
\hline Belemnites & Jurassic & UK & 0.06 & van de Schootbrugge et al. (2005) \\
\hline Belemnites & Jurassic & UK & 0.10 & Bailey et al. (2003) \\
\hline Belemnites & Jurassic & UK & 0.10 & Ullmann et al. (2014a) \\
\hline Belemnites & Jurassic & UK & 0.18 & Nunn and Price (2010) \\
\hline Belemnites & Jurassic & Russia & 0.18 & Price and Rogov (2009) \\
\hline Belemnites & Jurassic & New Zealand & 0.18 & Ullmann et al. (2013a) \\
\hline Belemnites & Jurassic & UK & 0.46 & Korte and Hesselbo (2011) \\
\hline Bivalves & Jurassic & UK & 0.06 & Jones et al. (1994) \\
\hline Bivalves & Jurassic & Poland & 0.18 & Wierzbowski and Joachimski (2007) \\
\hline Bivalves & Jurassic & UK & 0.46 & Korte and Hesselbo (2011) \\
\hline Bivalves & Triassic-Jurassic & UK & 0.46 & Korte et al. (2009) \\
\hline Brachiopods & Cretaceous & Denmark & 0.07 & Jelby et al. (2014) \\
\hline Brachiopods & Cretaceous & Europe & 0.18 & Voigt et al. (2003) \\
\hline Brachiopods & Jurassic & UK & 0.46 & Korte and Hesselbo (2011) \\
\hline Brachiopods & Triassic & New Caledonia & 0.20 & Ullmann et al. (2014b) \\
\hline Brachiopods & Triassic & Europe & 0.46 & Korte et al. (2005a) \\
\hline Brachiopods & Permian-Triassic & Europe & 0.46 & Korte et al. (2003) \\
\hline Brachiopods & Permian & global & 0.46 & Korte et al. (2005b) \\
\hline Brachiopods & Permian & global & 0.46 & Korte et al. (2006) \\
\hline Brachiopods & Permian & global & 0.46 & Korte et al. (2008) \\
\hline Brachiopods & Carboniferous & Europe & 0.36 & Bruckschen et al. (1999) \\
\hline Brachiopods & Carboniferous & Belgium & 0.64 & Bruckschen and Veizer (1997) \\
\hline
\end{tabular}


Isotope and element ratios in diagenetic calcite cements

\begin{tabular}{|c|c|c|c|c|c|c|c|c|}
\hline Locality & Age & Description & $n$ & $\begin{array}{c}\delta^{18} \mathrm{O} \\
\% \text { PDB }\end{array}$ & $\begin{array}{c}\delta^{13} \mathrm{C} \\
\% \circ \mathrm{PDB}\end{array}$ & \begin{tabular}{|c|}
$\mathrm{Sr} / \mathrm{Ca}$ \\
$\mathrm{mmol} / \mathrm{mol}$
\end{tabular} & $\begin{array}{c}\mathrm{Mn} / \mathrm{Ca} \\
\mathrm{mmol} / \mathrm{mol}\end{array}$ & Source \\
\hline UK, Yorkshire & Early Jurassic & $\begin{array}{c}\text { alveolar } \\
\text { cements } \\
\text { in belemnites }\end{array}$ & 20 & $\begin{array}{c}(-15.7)-(-9.0) \\
(-13.8)\end{array}$ & $\begin{array}{c}(-10.2)-(-3.2) \\
(-7.8)\end{array}$ & & & Sælen et al. (1996) \\
\hline $\begin{array}{l}\text { New Caledonia, } \\
\text { Ile Hugon }\end{array}$ & Late Triassic & $\begin{array}{l}\text { sparry calcite } \\
\text { in brachiopod }\end{array}$ & 14 & $\begin{array}{c}(-12.8)-(-10.6) \\
(-12.3)\end{array}$ & $\begin{array}{c}(-21.4)-(-19.3) \\
(-19.9)\end{array}$ & $\begin{array}{c}0.04-0.13 \\
(0.05)\end{array}$ & $\begin{array}{c}1.2-2.4 \\
(2.1)\end{array}$ & $\begin{array}{c}\text { Ullmann et al. } \\
(2014 \mathrm{~b})\end{array}$ \\
\hline UK, Isle of Man & Carboniferous & $\begin{array}{c}\text { zoned calcite } \\
\text { cements }\end{array}$ & 21 & $\begin{array}{c}(-12.4)-(-0.4) \\
(-7.2)\end{array}$ & $\begin{array}{c}(+1.2)-(+3.8) \\
(+2.7)\end{array}$ & & & $\begin{array}{c}\text { Dickson and } \\
\text { Coleman (1980) }\end{array}$ \\
\hline UK, Isle of Man & Carboniferous & vein calcite & 1 & -13.4 & +0.0 & & & $\begin{array}{c}\text { Dickson and } \\
\text { Coleman (1980) }\end{array}$ \\
\hline UK, Isle of Man & Carboniferous & $\begin{array}{l}\text { late calcite } \\
\text { cements }\end{array}$ & 3 & $\begin{array}{c}(-3.9)-(-4.3) \\
(-4.0)\end{array}$ & $\begin{array}{c}(-5.2)-(-8.0) \\
(-7.3)\end{array}$ & & & $\begin{array}{c}\text { Dickson and } \\
\text { Coleman (1980) } \\
\end{array}$ \\
\hline UK, Isle of Man & Carboniferous & dolomite & 7 & $\begin{array}{c}(-13.7)-(-6.2) \\
(-8.7)\end{array}$ & $\begin{array}{c}(+0.9)-(+3.3) \\
(+2.6)\end{array}$ & & & $\begin{array}{c}\text { Dickson and } \\
\text { Coleman (1980) }\end{array}$ \\
\hline USA, Nevada & Carboniferous & $\begin{array}{c}\text { sparry marine } \\
\text { cement }\end{array}$ & 9 & $\begin{array}{c}(-5.2)-(-3.6) \\
(-4.1)\end{array}$ & $\begin{array}{c}(+0.3)-(+1.5) \\
(+0.8)\end{array}$ & $\begin{array}{c}0.13-0.23 \\
(0.18) \\
\end{array}$ & $\begin{array}{c}0.09-0.32 \\
(0.16)\end{array}$ & Brand (2004) \\
\hline USA, Nevada & Carboniferous & vein calcite & 1 & -15.1 & +0.2 & 0.16 & 0.01 & Brand (2004) \\
\hline $\begin{array}{l}\text { USA, } \\
\text { New Mexico }\end{array}$ & Carboniferous & $\begin{array}{c}\text { sparry marine } \\
\text { cement }\end{array}$ & 2 & $(-7.9)-(-6.6)$ & $(-4.5)-(-0.6)$ & $0.31-0.59$ & $1.7-2.6$ & Brand (2004) \\
\hline $\begin{array}{l}\text { USA, } \\
\text { New York State }\end{array}$ & \begin{tabular}{|l|} 
Upper Silurian- \\
Lower Devonian
\end{tabular} & cement & 39 & $\begin{array}{c}(-10.1)-(-4.2) \\
(-7.1)\end{array}$ & $\begin{array}{c}(-0.9)-(+3.0) \\
(+1.2)\end{array}$ & & & $\begin{array}{c}\text { Rush and Chafetz } \\
(1990)\end{array}$ \\
\hline $\begin{array}{l}\text { USA, } \\
\text { offshore Oregon }\end{array}$ & $\begin{array}{l}\text { Neogene- } \\
\text { Quaternary }\end{array}$ & $\begin{array}{c}\text { "northern area" } \\
\text { cement I }\end{array}$ & 7 & $\begin{array}{c}(+3.2)-(+5.0) \\
(+3.4)\end{array}$ & $\begin{array}{c}(-54.8)-(-45.6) \\
(-52.4)\end{array}$ & $\begin{array}{c}0.84-1.16 \\
\dagger\end{array}$ & & $\begin{array}{c}\text { Sample and Reid } \\
(1998)\end{array}$ \\
\hline $\begin{array}{l}\text { USA, } \\
\text { offshore Oregon }\end{array}$ & $\begin{array}{l}\text { Neogene- } \\
\text { Quaternary }\end{array}$ & $\begin{array}{c}\begin{array}{c}\text { "northern area" } \\
\text { cement II }\end{array} \\
\end{array}$ & 14 & $\begin{array}{c}(-12.9)-(-4.3) \\
(-8.2)\end{array}$ & $\begin{array}{c}(-25.0)-(-1.0) \\
(-3.3)\end{array}$ & $\begin{array}{c}0.05-0.35 \\
(0.14) \ddagger \\
\end{array}$ & & $\begin{array}{c}\text { Sample and Reid } \\
(1998)\end{array}$ \\
\hline $\begin{array}{l}\text { USA, } \\
\text { offshore Oregon }\end{array}$ & $\begin{array}{l}\text { Neogene- } \\
\text { Quaternary }\end{array}$ & $\begin{array}{c}\text { Second ridge } \\
\text { cement }\end{array}$ & 21 & $\begin{array}{c}(+3.5)-(+9.3) \\
(+6.1)\end{array}$ & $\begin{array}{c}(-54.2)-(-0.6) \\
(-41.6)\end{array}$ & $\begin{array}{c}0.35-0.63 \\
(0.30) \cdot\end{array}$ & & $\begin{array}{c}\text { Sample and Reid } \\
(1998)\end{array}$ \\
\hline
\end{tabular}

$\dagger-\mathrm{n}=2, \ddagger-\mathrm{n}=8, \cdot-\mathrm{n}=5$

the assessment of fossil preservation, but similar caveats for availability and solubility in the diagenetic environment apply as for $\mathrm{Mn}$. Fe has been preferred over $\mathrm{Mn}$ as an alteration proxy in some instances (e.g., Jones et al., 1994) and a list of cutoff limits for good preservation is presented in Table 3. Similarly to $\mathrm{Mn} / \mathrm{Ca}$ upper limit ratios, the upper screening limit of $\mathrm{Fe} / \mathrm{Ca}$ varies considerably between the different authors (Table 3).

The application of Fe as an alteration proxy is hampered by the use of steel devices for fossil preparation and sample handling, which can easily lead to considerable iron contamination in the sample aliquots. Another difficulty is the usually much higher detection limit of Fe as compared to Mn when employing optical emission or absorption spectrometric techniques for quantification (e.g., Coleman et al., 1989; Rosales et al., 2001; Steuber and Buhl, 2006; Armendáriz et al., 2012).

$\mathrm{Fe}$ and $\mathrm{Mn}$ are elements that are present in very low concentrations in primary biogenic calcite but generally become enriched during post-depositional alteration of shell materials. Limiting $\mathrm{Fe} / \mathrm{Ca}$ ratios, like $\mathrm{Mn} / \mathrm{Ca}$ ratios, need to be evaluated for each study site. The analysis of both, Fe and Mn can be beneficial to assess diagenetic alteration of macrofossil calcite, because in this way element-specific heterogeneity of the diagenetic fluid can be (at least partially) counteracted.

\section{STRONTIUM IN LMC FOSSILS}

The Sr concentration in biogenic LMC is usually higher than $\mathrm{Sr}$ levels in thermodynamic equilibrium attainced in abiogenic calcite, causing Sr-depletion in calcite fossils during diagenesis (Carpenter and Lohmann, 1992; Figs. 5 and 6; see also Tang et al., 2008; DePaolo, 2011). Sr/Ca ratios - generally decreasing with progressive alteration - can therefore be employed for gauging the preservation state of fossil calcite shells (e.g., Bruckschen and Veizer, 1997; Korte et al., 2003; see Table 4 for applied limiting ratios).

The strict application of a lower Sr/Ca limit as an alteration marker, however, is problematic for several reasons. Primary $\mathrm{Sr} / \mathrm{Ca}$ ratios vary between and within fossil groups and in individual fossils (Veizer, 1974; Steuber and Veizer, 2002; Wierzbowski and Joachimski, 2009; Korte and Hesselbo, 2011; Li et al., 2012; Fig. 6). Such variability is caused by differing Sr incorporation into the calcite (Voigt et al., 2003; Wierzbowski and Joachimski, 2007) and can be related to vital effects (Lorens, 1981; Vander Putten et al., 2000; Shen et al., 2001; see discussion in Korte and Hesselbo, 2011). The former factor leads, for example, to a much higher incorporation of strontium into belemnite rostra than into ostreoid shells (Veizer, 1974; Rosales et al., 2004; Korte and Hesselbo, 2011; Ullmann et al., 2013c) and brachiopods (Voigt et al., 2003). In addition, secular changes in sea water $\mathrm{Sr} / \mathrm{Ca}$ through the Phanerozoic, possibly spanning a large range between 2 and $14 \mathrm{mmol} / \mathrm{mol}$ (Steuber and Veizer, 2002), constitute a further complication. In general, primary $\mathrm{Sr} / \mathrm{Ca}$ ratios are expected to be lower in LMC fossils from time intervals of Aragonite Seas than in fossils from Calcite Sea intervals (Steuber and Veizer, 2002). This pattern is primarily related to the incorporation of Sr into aragonite and calcite, where calcite precipitation leads to stronger increases in the $\mathrm{Sr} / \mathrm{Ca}$ ratio of residual sea water than the precipitation of aragonite due to the lower distribution coefficient for the former (Steuber and Veizer, 2002; Ullmann et al., 2013c).

Despite this primary variability, Sr/Ca ratios in shell samples can provide insight into their preservation state when carefully examining internal variability within datasets. Knowledge of the 
Upper limits for Fe/Ca ratios for well-preserved LMC macrofossils

\begin{tabular}{|l|c|c|c|c|}
\hline \multicolumn{1}{|c|}{ Material } & Age & Area & $\begin{array}{c}\text { Fe/Ca limit } \\
\mathrm{mmol} / \mathrm{mol}\end{array}$ & Source \\
\hline Belemnites & Cretaceous & Germany & 0.36 & Malkoc and Mutterlose (2010) \\
\hline Belemnites & Cretaceous & Germany & 0.36 & Mutterlose et al. (2010) \\
\hline Belemnites & Cretaceous & Hungary & 0.36 & Price et al. (2011) \\
\hline Belemnites & Cretaceous & Europe & 0.90 & Voigt et al. (2003) \\
\hline Belemnites & Jurassic-Cretaceous & Russia & 0.27 & Jones et al. (1994) \\
\hline Belemnites & Jurassic & UK & 0.27 & Price and Rogov (2009) \\
\hline Belemnites & Jurassic & Russia & 0.27 & Nunn and Price (2010) \\
\hline Belemnites & Jurassic & Scotland & 0.27 & Wierzbowski et al. (2009) \\
\hline Belemnites & Jurassic & Poland & 0.36 & Wierzbowski and Joachimski (2007) \\
\hline Belemnites & Jurassic & Poland & 0.36 & Price and Sellwood (1997) \\
\hline Belemnites & Jurassic & Falkland Plateau & 0.45 & Rosales et al. (2004) \\
\hline Belemnites & Jurassic & Spain & 0.45 & Benito and Reolid (2012) \\
\hline Belemnites & Jurassic & Spain & 0.54 & Jones et al. (1994) \\
\hline Bivalves & Jurassic & UK & 0.27 & Voigt et al. (2003) \\
\hline Bivalves & Jurassic & Poland & 0.45 & Wierzbowski and Joachimski (2007) \\
\hline Brachiopods & Cretaceous & Europe & 0.90 & (2004) \\
\hline
\end{tabular}

Table 4

Lower limits for Sr/Ca ratios for well-preserved LMC macrofossils

\begin{tabular}{|l|c|c|c|c|}
\hline \multicolumn{1}{|c|}{ Material } & Age & Area & $\begin{array}{c}\text { Sr/Ca limit } \\
\text { mmol/mol }\end{array}$ & Source \\
\hline Belemnites & Jurassic & UK & 0.46 & Korte and Hesselbo (2011) \\
\hline Belemnites & Jurassic & Spain & 1.03 & Rosales et al. (2004) \\
\hline Belemnites & Jurassic & UK & 1.20 & Ullmann et al. (2014a) \\
\hline Bivalves & Triassic-Jurassic & UK & 0.46 & Korte et al. (2009) \\
\hline Bivalves & Jurassic & UK & 0.46 & Korte and Hesselbo (2011) \\
\hline Brachiopods & Cretaceous & Denmark & 1.40 & Jelby et al. (2014) \\
\hline Brachiopods & Carboniferous & Belgium & 0.69 & Bruckschen and Veizer (1997) \\
\hline Brachiopods & Permian-Triassic & Europe & 0.46 & Korte et al. (2003) \\
\hline Brachiopods & Triassic & Europe & 0.46 & Korte et al. (2005a) \\
\hline Brachiopods & Permian & global & 0.46 & Korte et al. (2005b) \\
\hline Brachiopods & Permian & global & 0.46 & Korte et al. (2006) \\
\hline Brachiopods & Permian & global & 0.46 & Korte et al. (2008) \\
\hline Brachiopods & Jurassic & UK & 0.46 & Korte and Hesselbo (2011) \\
\hline
\end{tabular}

original composition of samples from closely related species of the same age and/or multi-proxy datasets, however, is required for a (semi-)quantitative assessment.

\section{SODIUM IN LMC FOSSILS}

Sodium is suggested to be another proxy for diagenetic alteration (see Brand and Veizer, 1980; Veizer, 1983a; Al-Aasm and Veizer, 1986a; Grossman et al., 1996). However, this element is weakly bound in the calcite lattice, often connected with fluid inclusions and its primary concentration in LMC shells is believed to be metabolically controlled (Grossman et al., 1996). Hence, it is difficult to set limiting $\mathrm{Na} / \mathrm{Ca}$ ratios for well-preserved calcites and $\mathrm{Na} / \mathrm{Ca}$ ratios are seldom used to describe fossil preservation.

\section{COMBINED TRACE ELEMENT TECHNIQUES}

The contrasting geochemical behaviour of trace elements during diagenesis can be employed in the form of element ratios which are strongly indicative of post-depositional processes. $\mathrm{Mn} / \mathrm{Ca}$ and $\mathrm{Sr} / \mathrm{Ca}$ ratios can be combined for assessing 
the degree of diagenetic alteration in macrofossil calcite (e.g., Rosales et al., 2001; Shields et al., 2003; Brand, 2004; Mette et al., 2012), because a clear negative correlation between these ratios in datasets including partially altered material is predicted. In primary biogenic calcite the $\mathrm{Sr} / \mathrm{Mn}$ ratio is expected to be high, whereas it is low in diagenetic phases. The employed lower limits of this ratio are highly variable $(2-80 \mathrm{~g} / \mathrm{g})$ among different authors (Rosales et al., 2001; Shields et al., 2003; Brand, 2004; Mette et al., 2012) because of the previously discussed dissimilar $\mathrm{Mn}$ and $\mathrm{Sr}$ concentrations in both primary fossil shells and in diagenetic settings.

In some instances, principal component analysis of multiproxy datasets is employed for the interpretation of fossil preservation (e.g., Brand and Veizer, 1981; Al-Aasm and Veizer, 1986b). The multidimensional direction of principal component vectors can be used to assess how much of the internal variability in a dataset may be related to diagenetic effects. The principal component of diagenesis is chosen such that the loadings of its constituent variables are compatible with commonly observed diagenetic trends (e.g., Sr having a loading with a sign opposite to the loadings of $\mathrm{Mn}$ and $\mathrm{Fe}$ ). This approach presupposes, however, that all processes generating the variability in the observed data can be approximated by linear trends. This assumption can at best hold for cementation in open diagenetic systems, but is likely insufficient to accurately describe closed diagenetic systems where incorporation of these elements is not linear.

\section{NON-STATIC APPROACHES}

The problems of static limits of element concentrations for identifying alteration have been recognized, e.g. leading to the use of Dynamic Elemental Limits (Brand et al., 2007). Here, the sedimentary succession is subdivided into multiple zones for which the elemental trends are evaluated separately. This approach honours the fact that quantitative trends of diagenesis can be spatially highly variable (Tables 1-3) and enables treating lithological units separately. It can only be usefully employed, however, if a statistically significant amount of data exists for any stratigraphic subdivision. Furthermore, this approach does not resolve the problem of existing species-specific modulation of elemental (and isotopic) ratios. An additional requirement for this method is that the data of each allocated unit should be derived from the same or at least similar fossil taxa, which in most cases is unrealistic when reconstructing palaeoenvironment changes over long time spans (e.g., Veizer et al., 1999; Korte and Hesselbo, 2011).

\section{ISOTOPIC TRENDS OF ALTERATION}

Isotope ratios of elements can be affected by diagenesis and some isotopic proxies can be efficient tools for deciphering diagenetic trends that may remain unnoticed or ambiguous when only employing the previously discussed textural and elemental proxies. All studied isotopic systems with long oceanic residence times have been found to have undergone secular variations in the Phanerozoic (e.g., Veizer et al., 1999; Prokoph et al., 2008; Blättler et al., 2012; Misra and Froelich, 2012; Vollstaedt et al., 2014). Such secular variation can aid in the identification of diagenetic effects, but can potentially also be confused with diagenesis and/or obscure signatures of post-depositional alteration, where long time intervals are being studied.

\section{$\delta^{13} \mathrm{C}$ AND $\delta^{18} \mathrm{O}$ AND THEIR CO-VARIATION}

It is a common observation that calcite cements and heavily altered shell materials are depleted in the heavy carbon and oxygen isotopes (e.g., Brand and Veizer, 1981; AlAasm and Veizer, 1986a, b; Marshall, 1992; Sælen et al., 1996; Table 2). There are, however, a number of potential diagenetic settings, where this post-depositional alteration trend is not present (Fig. 8). For carbon isotopes, diagenesisrelated ${ }^{13} \mathrm{C}$-depletions are mostly due to the influence of oxidized isotopically light organic carbon phases contributing to the dissolved inorganic carbon pool of the diagenetic fluid (e.g., Al-Aasm and Veizer, 1986a, b; Marshall, 1992; Fig. 8). A minor increase in the fractionation factor for carbon between bicarbonate and the carbonate ions with increasing temperature $\left(+0.06 \pm 0.02 \% /{ }^{\circ} \mathrm{C}\right.$ at $\left.20^{\circ} \mathrm{C}\right)$ may lead to slightly less pronounced uptake of light carbon in calcite fossils suffering from diagenetic alteration under deep burial conditions (Emrich et al., 1970). This effect is likely of subordinate importance in most diagenetic settings, though. Diagenesis-related increases in $\delta^{13} \mathrm{C}$ values are possible, where the dissolved inorganic carbon of the diagenetic fluid is derived from carbonbearing phases with a very positive $\delta^{13} \mathrm{C}$ signature, e.g. some Proterozoic and Late Paleozoic carbonates (Veizer et al., 1999; Prokoph et al., 2008).

Decreases in $\delta^{18} \mathrm{O}$ values during diagenesis can be related to the influence of ${ }^{18} \mathrm{O}$-depleted meteoric waters as well as to elevated temperatures during post-depositional alteration (e.g., Brand and Veizer, 1981; Al-Aasm and Veizer, 1986a, b; Fig. 8). Rarely considered controls on diagenetic changes in $\delta^{18} \mathrm{O}$ are isotopic disequilibrium effects between the different molecules in the diagenetic fluid that contain oxygen due to slow isotopic exchange amongst these molecules (Watkins et al., 2013). Both increased precipitation rate and increased $\mathrm{pH}$ can lead to a lowering of the apparent oxygen fractionation factor between solution and calcite (Zeebe, 2007; Watkins et al., 2013) which can amount to $\delta^{18} \mathrm{O}$ depletions of several permil in diagenetic calcite. Alteration trends towards more positive $\delta^{18} \mathrm{O}$ values are possible and have been observed, e.g. through early marine cement formation in cold bottom waters and interaction with evolved hydrothermal fluids (Sample and Reid, 1998).

The effect of alteration on calcite $\delta^{18} \mathrm{O}$ is commonly larger than that for calcite $\delta^{13} \mathrm{C}$ (Banner and Hanson, 1990; Brand, 2004) because aqueous diagenetic fluids contain $>27 \mathrm{~mol} / \mathrm{L}$ oxygen, but only a few $\mathrm{mmol} / \mathrm{L}$ carbon. This concentration contrast itself, however, does not explain the usually more robust nature of the carbon isotope signal to diagenetic alteration. The precipitation of carbonate from a diagenetic fluid will always incorporate $\mathrm{C}$ and $\mathrm{O}$ in the ratio of $1: 3\left(\mathrm{CO}_{3}^{2-}\right)$ regardless of the actual concentrations of these elements in the fluid. In contrast to oxygen, however, a substantial fraction of carbon in the diagenetic fluid might be derived from dissolution of metastable carbonate phases with isotopic ratios similar to the pristine fossil values, buffering the primary $\delta^{13} \mathrm{C}$ values during alteration (see also Veizer, 1983a).

The coupled uptake and incorporation of light carbon and oxygen during alteration results in a positive $\delta^{13} \mathrm{C} / \delta^{18} \mathrm{O}$ correlation in the diagenetic carbonate. As discussed above, it should not be expected that diagenesis necessarily generates such a correlation, but post-depositional alteration leading to opposing or lacking correlation between these two isotopic systems are rare occurrences rather than the norm. Positive correlations between carbon and oxygen isotopes, can also be produced when plotting data from shell materials that are affected by kinetic iso- 


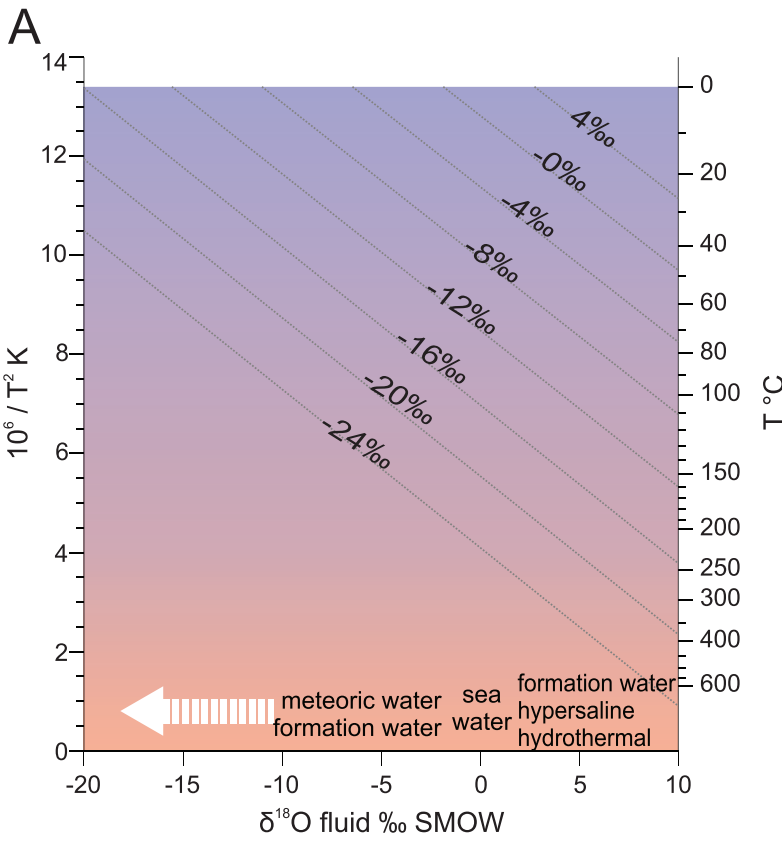

B

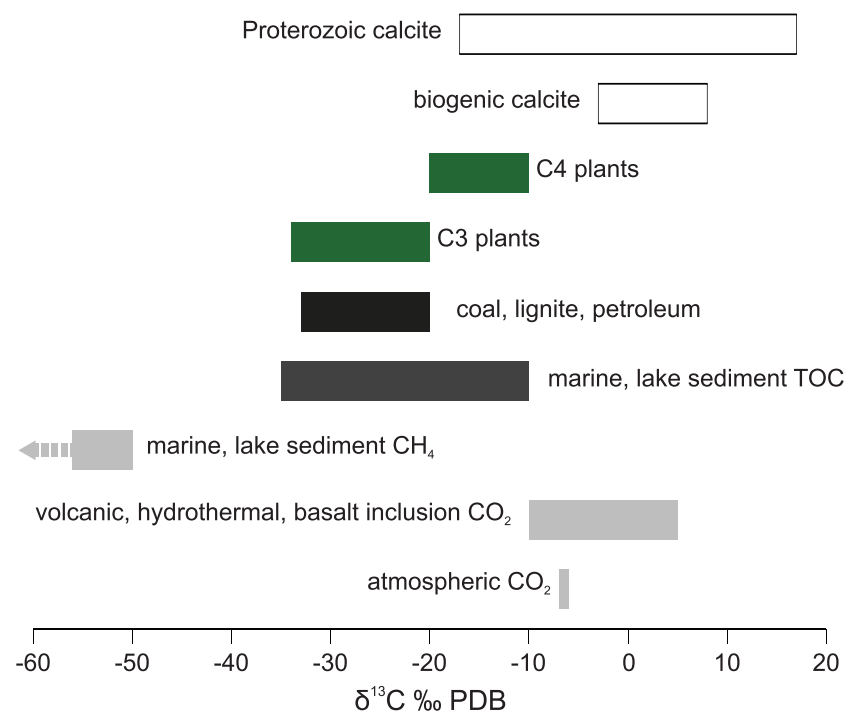

Fig. 8. Isotopic composition of calcite depending on the diagenetic environment

A- equilibrium $\delta^{18} \mathrm{O}$ values of calcite are defined by fluid composition and temperature; stippled isolines for $\delta^{18} \mathrm{O}$ values in calcite in \%o PDB are computed from O'Neil et al. (1969); B - carbon isotopic composition of selected carbon reservoirs (ranges taken from Sharp, 2007); biogenic and Proterozoic calcite from Prokoph et al. (2008); the $\delta^{13} \mathrm{C}$ value of diagenetic calcite depends on which of these carbon pools contributes the most to the diagenetic fluid; the large number of possible combinations of physicochemical settings allows for a wide array of diagenetic trends, of which the most commonly reported points to lower $\delta^{13} \mathrm{C}$ and $\delta^{18} \mathrm{O}$ values

tope fractionation effects (e.g., Wefer and Berger, 1991; Parkinson et al., 2005). In very few instances, primary co-variation of carbon and oxygen ratios in carbonates with negative $\delta^{13} \mathrm{C}$ and $\delta^{18} \mathrm{O}$ values are observed (e.g., during the Toarcian Oceanic Anoxic Event; Hermoso et al., 2012).

$$
{ }^{87} \mathrm{Sr} /{ }^{86} \mathrm{Sr} \text { RATIOS }
$$

The ${ }^{87} \mathrm{Sr} /{ }^{86} \mathrm{Sr}$ ratios of fossil materials enable assessment of diagenetic alteration in marine fossil shells (e.g., Brand, 1991; Ullmann et al., 2013a; Wierzbowski, 2013) because this isotope ratio is uniform in a primary biogenic carbonate. Changes in sea water ${ }^{87} \mathrm{Sr} /{ }^{86} \mathrm{Sr}$ ratios exceeding analytical reproducibility only occur on timescales of several hundred kyrs to several Myrs (McArthur et al., 2001; Brand et al., 2003). Biological fractionation of the ${ }^{87} \mathrm{Sr} /{ }^{86} \mathrm{Sr}$ isotope ratio is compensated (Elderfield, 1986) due to the normalization of the ${ }^{87} \mathrm{Sr} /{ }^{86} \mathrm{Sr}$ ratio to an accepted ${ }^{86} \mathrm{Sr} /{ }^{88} \mathrm{Sr}$ ratio of 0.1194 in standard applications (Nier, 1938; see above, however). Potential radiogenic ingrowth of ${ }^{87} \mathrm{Sr}$ in shell calcite due to the presence of $\mathrm{Rb}$ (Banner, 1995) is unlikely to play a significant role for well-preserved fossils even in the Paleozoic because $\mathrm{Rb}$ is an incompatible element in calcite (Okumura and Kitano, 1986) leading to $\mathrm{Sr} / \mathrm{Rb}$ ratios above 1000 in biogenic carbonates (Banner and Kaufman, 1994; Zhang, 2009). Any variability of ${ }^{87} \mathrm{Sr} /{ }^{86} \mathrm{Sr}$ ratios in individual marine fossil shells which are beyond the analytical uncertainty and/or significant deviation from the marine strontium isotope reference curve (Howarth and McArthur, 1997; McArthur et al., 2001) are thus expected to be caused by partial diagenetic overprints (but see Eidvin et al., 2014 for caveats).
It is advisable to split fossil samples taken for ${ }^{87} \mathrm{Sr} /{ }^{86} \mathrm{Sr}$ analysis into a subsample for ${ }^{87} \mathrm{Sr} /{ }^{86} \mathrm{Sr}$ ratio analysis and a subsample for trace element analysis after dissolution to gain additional information about sample preservation unbiased by heterogeneity of the specimen (e.g., Ullmann et al., 2013a, 2014b).

To reach its full potential as a tool for the assessment of diagenetic alteration, a series of ${ }^{87} \mathrm{Sr} /{ }^{86} \mathrm{Sr}$ determinations on a single fossil shell should be conducted. This method can only be applied to relatively large shells of animals living in fully marine conditions, where potential variable contributions of fresh water-derived Sr (see Wierzbowski et al., 2012) can be ruled out.

\section{LESS WELL-INVESTIGATED ISOTOPE SYSTEMS}

Biogenic carbonates have recently received increasing attention as substrates for analyses of less well-investigated isotopic systems such as $\mathrm{Li}, \mathrm{Mg}, \mathrm{S}, \mathrm{Ca}, \mathrm{Cr}$ and (stable isotope) $\mathrm{Sr}$ $\left(\delta^{88} \mathrm{Sr}\right)$ (e.g., Finnegan et al., 2011; Gill et al., 2011; Blättler et al., 2012; Misra and Froelich, 2012; Frei et al., 2013; Vollstaedt et al., 2014).

A future challenge will be to provide information on the diagenetic behaviour of the ever increasing number of isotopic systems studied in fossil materials. Under the assumption that all elements respond similarly to diagenetic reactions, dedicated studies on the diagenetic behaviour of such isotopic systems may appear futile. Other proxies than the newly studied isotopic systems could then be used to exclude altered samples from further interpretation instead. It is, however, not immediately clear whether the same physicochemical behaviour applies to all elements and compounds in biogenic carbonates. 
Different operating processes might de-couple diagenetic trends of different tracers. In particular, the potential for diffusion as a diagenetic process might be highly specific to each element and compound. For this reason, a robust knowledge of potential diagenetic trends in newly investigated isotope systems is necessary to answer this fundamental question: is interpretation of these new proxies plausible in terms of palaeoenvironmental conditions, or is diagenesis responsible for generating the observed signal? Recent findings on this topic are summarized below.

$\delta^{7} \mathrm{Li}$. Late Jurassic belemnite rostra from New Zealand, showing good textural preservation and only minor geochemical evidence for diagenesis, have uniform $\delta^{7} \mathrm{Li}$ with values $\sim+27 \%$ L-SVEC which are similar to those of modern sea water (Ullmann et al., 2013a). Samples that are derived from clearly altered parts of the rostra show higher $\delta^{7} \mathrm{Li}$ values of up to $+40 \%$ and tending towards higher Li/Ca ratios (UIImann et al., 2013a). These findings suggest that primary $\delta^{7} \mathrm{Li}$ values can be preserved in macrofossil calcite over geological time spans. Alteration of $\delta^{7} \mathrm{Li}$ appears to be related to dissolution-reprecipitation reactions rather than diffusional processes. The latter seems to play only a subordinate role for this isotopic system in fossil carbonates. Further studies are required to assess whether the diagenetic trends observed for the Late Jurassic of New Zealand are representative.

Clumped isotopes of $\mathbf{C}$ and $\mathbf{O}$. The clumped isotope thermometer operates on the basis of the observation that $\mathrm{C}-\mathrm{O}$ bonds in carbonates exhibit an overrepresentation of bonds of heavy isotopes (e.g., ${ }^{13} \mathrm{C}^{17} \mathrm{O}^{16} \mathrm{O}^{16} \mathrm{O}^{2-}$ and ${ }^{13} \mathrm{C}^{18} \mathrm{O}^{16} \mathrm{O}^{16} \mathrm{O}^{2-}$ ) over the amount that can be computed from statistical probabilities. The degree of enrichment of these bonds amongst heavy isotopes over the number predicted from random distribution of isotopes is temperature-dependent and based only on isotopic equilibrium in the carbonate ion; this thermometer thus can operate without assumptions on the isotopic composition of ambient water (e.g., Eiler, 2007 , 2011). Naturally, this isotopic proxy is affected by the same diagenetic processes as all other geochemical proxies, but because it relies on the preservation of single atomic/ionic bonds, additionally solid state diffusion may play a much more profound role over extended time spans (e.g., Dennis and Schrag, 2010). Recent studies suggest that blocking temperatures for the diffusion of $\mathrm{C}$ and $\mathrm{O}$ are sufficiently high to enable preservation of the clumped isotope signature of biogenic carbonates over geological time spans (Dennis and Schrag, 2010; Finnegan et al., 2011; Henkes et al., 2014). The results of Henkes et al. (2014) indicate that incipient re-ordering in brachiopod calcite ( $1 \%$ re-equilibration) will have occurred only after 109 years at burial temperatures of $\sim 90^{\circ} \mathrm{C}$, and 107 years at temperatures of $\sim 115^{\circ} \mathrm{C}$. These results encourage the hopes that clumped isotope thermometry will be able to significantly contribute to our understanding of past environments.

$\delta^{26} \mathrm{Mg}$. We are not aware of any dedicated study investigating diagenetic impacts on $\delta^{26} \mathrm{Mg}$ in biogenic carbonates in general and LMC fossils specifically. Compiled datasets indicate that diagenetic effects on $\delta^{26} \mathrm{Mg}$ values in LMC fossils will be difficult to constrain independently, because species with both lighter and heavier $\delta^{26} \mathrm{Mg}$ values than those of abiogenic precipitates have been observed (Saenger and Wang, 2014). Fossil-derived datasets are therefore expected to be difficult to interpret in terms of past environments and diagenetic changes, unless special care is taken to investigate only monospecific samples. $\delta^{34} S$. Meteoric diagenesis of $\delta^{34} S$ values of carbonate-associated sulphate (CAS) has been studied by Gill et al. (2008). They found that alteration led to a strong decrease in CAS concentration, but isotopic effects in the studied material (Pleistocene Key Largo Limestone from Florida) were smaller than $2 \%$. It is predicted that in environments where sulphate reduction is prominent, removal of light sulphur from the sulphate in the fluid will lead to diagenetic signatures towards more heavy $\delta^{34} S$ values (Gill et al., 2008). The process of sulphide oxidation on the other hand would supply isotopically light sulphur to the diagenetic fluid that would then lead to lower $\delta^{34} S$ values in the diagenetic calcite (Gill et al., 2008).

$\delta^{44} \mathrm{Ca}$. $\delta^{44} \mathrm{Ca}$ values are expected to be relatively robust against partial diagenetic overprints, because $\mathrm{Ca}$ is the most abundant cation in LMC, accounting for almost 40 weight percent of the material. Some inferences about expected diagenetic trends can be made on the basis of observations in ODP sites (Fantle et al., 2010), predicting increasing $\delta^{44} \mathrm{Ca}$ values in diagenetic calcite, possibly related to slow precipitation rates of the secondary calcite (DePaolo, 2011).

$\delta^{53} \mathrm{Cr}$. Very few data for $\delta^{53} \mathrm{Cr}$ in carbonates have been published and consequently the preservation potential of this proxy in biogenic carbonates is poorly constrained. Concentrations of $\mathrm{Cr}$ in carbonates (a few tens of $\mu \mathrm{g} / \mathrm{g}$ at most, Frei et al., 2013) are very low compared to concentrations in silicates. Contamination effects and diagenetic fluids carrying a silicate-derived $\delta^{53} \mathrm{Cr}$ signature could therefore easily affect the $\mathrm{Cr}$ isotope composition of LMC biogens.

$\delta^{88} \mathrm{Sr}$. In the 2014 compilation of $\delta^{88} \mathrm{Sr}$ values of biogenic carbonates through the Phanerozoic, a few samples deemed diagenetically overprinted show a tendency towards more positive $\delta^{88} \mathrm{Sr}$ values (Vollstaedt et al., 2014: table 1). A study exploring diagenetic effects on this isotope system in pore waters and carbonates from sites of IODP expedition 320/321 yielded the opposite result, predicting that diagenetic calcite becomes enriched in light Sr isotopes (Voigt et al., 2015).

\section{QUALITATIVE AND QUANTITATIVE DIAGENETIC IMPACT}

The conceptual foundations for variably complicated models aiming to reconstruct primary values for geochemical proxies of partly altered materials have been established (e.g., Veizer and Fritz, 1976; Banner and Hanson, 1990; Banner, 1995; Ray et al., 2003). These efforts are driven by the desire to quantify diagenetic effects and to derive pristine palaeoenvironmental data.

For the application of such models, some requirements have to be fulfilled:

- the alteration mechanism (e.g., cementation) has to be common to all proxies used for palaeoenvironmental reconstructions;

- the interaction can be described as a binary system, comprising a fossil and a diagenetic end member. If more end members need to be invoked, less precise estimates and non-unique solutions may result;

- the compositional range of the end members has to be sufficiently uniform and distinct to allow for a precise estimate of the primary values of geochemical proxies in the shell calcite;

- for at least one proxy, the original composition of the fossil calcite needs to be known. 

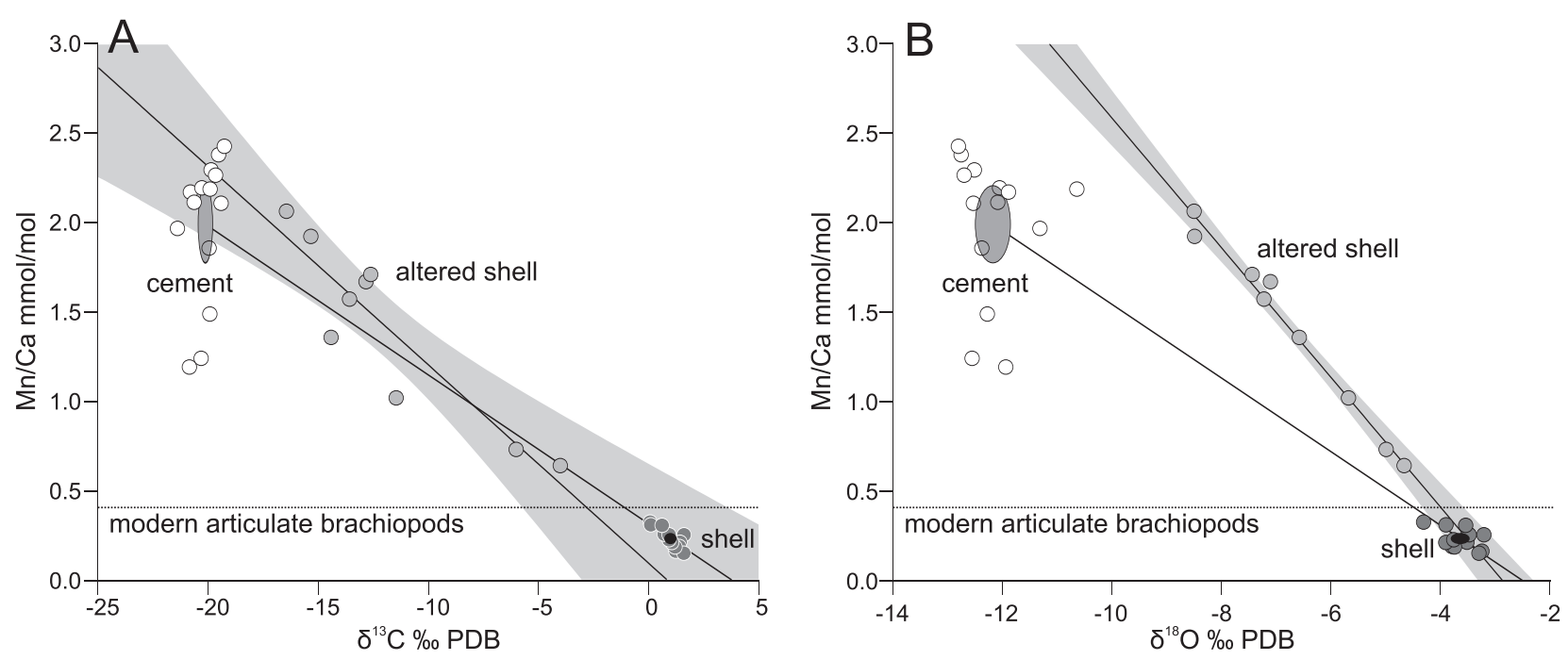

Fig. 9. Geochemical proxies in sparry calcite cement and shell calcite of a Late Triassic brachiopod (Clavigera planchesi) from New Caledonia (data from Ullmann et al., 2014b)

A - Mn/Ca ratios versus $\delta^{13} \mathrm{C}$ values; $\mathbf{B}-\mathrm{Mn} / \mathrm{C}$ a ratios versus $\delta^{18} \mathrm{O}$ values; white circles - sparry cement, light grey circles - visibly altered shell materials containing a cement fraction, grey circles - shell calcite; mean cement composition (white ellipse) and mean shell composition (black ellipse) are shown with 2 standard error uncertainty; linear regressions through the altered shell data are shown as grey trends line with light grey $95 \%$ uncertainty band; the maximum $\mathrm{Mn} / \mathrm{Ca}$ ratio observed in extant articulate brachiopods (Brand et al., 2003) is shown as a stippled line; potential extrapolation of data to pristine end members is hampered by heterogeneity of the cements, unclear $\mathrm{Mn} / \mathrm{Ca}$ composition of original shell material and a diagenetic process which can only insufficiently be described by a binary mixing of shell calcite and sparry cement

Complications in reconstructing original fossil composition arise because geochemical proxies can be variably affected by different diagenetic settings. Additionally, considerably different imprints of consecutive diagenetic stages at a single locality, and within carbonate cements of a single diagenetic phase, are observed (Table 2 and Fig. 9). Figure 9 exemplifies these issues for a calcite-cemented Late Triassic brachiopod shell from New Caledonia. The geochemical signatures of sparry cements and shell material are distinct, but numerous problems arise in the potential reconstruction of original proxy values: (i, ii) $-\delta^{13} \mathrm{C}$ versus $\mathrm{Mn} / \mathrm{Ca}$ systematics are compatible with a simple cementation process, but $\delta^{18} \mathrm{O}$ values deviate significantly from a binary mixing line, suggesting an additional controlling factor during the diagenetic process; (iii) - the calcite cement is compositionally distinct from the shell, but too heterogeneous to estimate a precise end member. Linear trend lines defined by partly altered samples are too poorly defined to be of use for precise estimates of original composition of $\delta^{13} \mathrm{C}$ values; (iv) there is no trace element proxy in shell material whose pristine value is accurately known. Original $\mathrm{Sr} / \mathrm{Ca}, \mathrm{Mg} / \mathrm{Ca}$ and $\mathrm{Na} / \mathrm{Ca}$ ratios may be variable and depend strongly on the species. $\mathrm{Mn} / \mathrm{Ca}$ and $\mathrm{Fe} / \mathrm{Ca}$ ratios in extant species are significantly higher than zero (e.g., Brand et al., 2003), thus making a linear extrapolation of geochemical proxies to zero problematic. Figure 9B pictures this problem: a set of data points shows $\mathrm{Mn} / \mathrm{Ca}$ ratios compatible with the range spanned by modern brachiopod data. Without a well-defined original $\mathrm{Mn} / \mathrm{Ca}$ ratio, however, it cannot be objectively decided which oxygen isotope ratio would represent original values, and how far alteration trends should be extrapolated. These observations show that in many cases diagenetic trends cannot be characterized well enough to precisely quantify the preservation degree of investigated samples (but see Jelby et al., 2014). Nevertheless, a comprehensive analysis of the composition of diagenetic phases, together with testing of different models of diagenetic changes, provide critical information about the preservation state of investigated geochemical proxies in fossil materials. In addition, a careful characterization of diagenetic alteration provides important insights into the post-depositional history of the samples.

\section{CONCLUSIONS}

Fossil biogenic LMC can carry geochemical information from the past and is therefore a preferred target to investigate/elucidate environmental and climate changes in Earth history. Understanding diagenetic alteration and excluding altered samples is essential to ensure accurate results and robust interpretations.

Optical and chemical techniques for assessing diagenetic alteration in biogenic LMC all have specific strengths and pitfalls and none of these techniques are sufficient as a stand-alone test for the preservation state of LMC (Table 5). It is therefore advisable to use a combination of several (many) of these techniques to best evaluate the preservation state of fossil materials. It is also recommended to petrographically and chemically describe associated diagenetic calcite phases (veins, cements etc.) in order to derive quantitative information about the composition and appearance of the diagenetic end member(s) (Mii et al., 1999; Grossman, 2012). To avoid the biasing effects of small scale heterogeneity within shell material, elemental and isotopic ratios 
Advantages and caveats for techniques used to assess the preservation state of macrofossil calcite

\begin{tabular}{|c|c|c|}
\hline Screening technique & Advantages & Caveats \\
\hline Optical microscopy & easy; inexpensive; rapid & qualitative; limited to macroscopic appearance \\
\hline $\begin{array}{l}\text { Scanning Electron } \\
\text { Microscopy }\end{array}$ & $\begin{array}{l}\text { fine-scale assessment } \\
\text { of ultrastructural preservation }\end{array}$ & $\begin{array}{l}\text { qualitative; limited to appearance of surfaces and fractures; } \\
\text { potential bias due to heterogeneous preservation of specimens }\end{array}$ \\
\hline Cathodoluminescence & $\begin{array}{l}\text { spatially resolved } \\
\text { preservation mapping }\end{array}$ & false positive and negative tests possible \\
\hline $\mathrm{Mn} / \mathrm{Ca}$ ratios & $\begin{array}{l}\text { (semi-)quantitative; } \\
\text { easily measurable }\end{array}$ & $\begin{array}{l}\text { need to be calibrated for fossil type, diagenetic setting; } \\
\text { can yield highly heterogeneous data in (semi-)closed systems }\end{array}$ \\
\hline $\mathrm{Fe} / \mathrm{Ca}$ ratios & $\begin{array}{l}\text { (semi-)quantitative; } \\
\text { easily measurable }\end{array}$ & $\begin{array}{l}\text { need to be calibrated for fossil type, diagenetic setting; can yield highly } \\
\text { heterogeneous data in (semi-)closed systems; contamination potential }\end{array}$ \\
\hline $\mathrm{Sr} / \mathrm{Ca}$ ratios & $\begin{array}{l}\text { (semi-)quantitative; } \\
\text { easily measurable }\end{array}$ & need to be calibrated for fossil type, diagenetic setting \\
\hline$\delta^{13} \mathrm{C}, \delta^{18} \mathrm{O}$ values & $\begin{array}{l}\text { (semi-)quantitative; } \\
\text { easily measurable }\end{array}$ & $\begin{array}{c}\text { need to be calibrated for fossil type, diagenetic setting; } \\
\text { potential for circular reasoning }\end{array}$ \\
\hline${ }^{87} \mathrm{Sr} /{ }^{86} \mathrm{Sr}$ ratios & $\begin{array}{l}\text { (semi-)quantitative; } \\
\text { very reliable and sensitive }\end{array}$ & $\begin{array}{l}\text { require comparatively large specimens for multiple samples; only applicable } \\
\text { in fully marine settings; limited number of samples can be analysed }\end{array}$ \\
\hline
\end{tabular}

should be analysed sequentially on the same sample aliquot (Coleman et al., 1989). The quality of the assessment of fossil preservation state is likely to improve if phylogenetic complexities, lithological variability and potential secular changes of climate and sea water composition are taken into account.

Flowcharts and diagrams for checking fossil preservation state have been published in various forms (e.g., Marshall, 1992; Sharp, 2007; Grossman, 2012) and can be taken as templates for establishing working routines for assessing sample preservation. The following series of observations supports (but does not prove) that sample preservation is good and palaeoenvironmental interpretation is possible:

- shell calcite is slightly translucent and shows biogenic structure (shell fibres, sheets, radial crystals etc.);

- ultrastructure (SEM) is preserved and crystal surfaces are smooth;

- shell material is non-luminescent, shows intrinsic luminescence, or luminescence can be shown to be related to primary uptake of trace elements in biogenic calcite (CL);

- concentrations of $\mathrm{Mn}$ and Fe are low and do not correlate negatively with $\mathrm{Sr} / \mathrm{Ca}$ ratios;

- $\mathrm{Mn} / \mathrm{Ca}, \mathrm{Fe} / \mathrm{Ca}$ and $\mathrm{Sr} / \mathrm{Ca}$ do not show correlation with $\delta^{13} \mathrm{C}$ and/or $\delta^{18} \mathrm{O}$ values;
- $\delta^{13} \mathrm{C}$ and $\delta^{18} \mathrm{O}$ values are not highly negative and do not show a strong (positive) correlation;

- ${ }^{87} \mathrm{Sr} /{ }^{86} \mathrm{Sr}$ ratios are uniform (in single specimens and successions spanning very short time intervals) and compatible with the marine ${ }^{87} \mathrm{Sr} /{ }^{86} \mathrm{Sr}$ isotope curve of the studied time;

- ${ }^{87} \mathrm{Sr} /{ }^{86} \mathrm{Sr}$ ratios are not correlated with $\mathrm{Sr} / \mathrm{Ca}, \mathrm{Mn} / \mathrm{Ca}$ or $\mathrm{Fe} / \mathrm{Ca}$ ratios;

- geochemical proxies in biogenic LMC deviate significantly from diagenetic carbonate phases;

- trend lines from potentially existing correlations between geochemical proxies in biogenic LMC cannot be extrapolated towards the composition of the diagenetic carbonate phases.

Acknowledgments. We thank N. Thibault for fruitful discussion about earlier versions of this manuscript. M. Jasionowski, H. Wierzbowski and two anonymous reviewers provided critical comments that helped to significantly improve the quality of this article. We acknowledge funding from the Deutsche Akademie der Naturforscher Leopoldina - German National Academy of Sciences (research grant no LPDS 2014-08) provided for CVU.

\section{REFERENCES}

Addadi, L., Joester, D., Nudelman, F., Weiner, S., 2006. Mollusk shell formation: a source of new concepts for understanding biomineralization processes. Chemistry - a European Journal, 12: 980-987.

Al-Aasm, I.S., Veizer, J., 1986a. Diagenetic stabilization of aragonite and low-Mg calcite, I. Trace elements in rudists. Journal of Sedimentary Petrology, 56: 138-152.

Al-Aasm, I.S., Veizer, J., 1986b. Diagenetic stabilization of aragonite and low-Mg calcite, II. Stable isotopes in rudists. Journal of Sedimentary Petrology, 56: 763-770.

Algeo, T.J., Maynard, J.B., 2004. Trace-element behaviour and redox facies in core shales of Upper Pennsylvanian Kansas-type cyclothems. Chemical Geology, 206: 289-313.

Almeida, M.J., Machado, J., Moura, G., Azevedo, M., Coimbra, J., 1998. Temporal and local variations in biochemical composition of Crassostrea gigas shells. Journal of Sea Research, 40: 233-249.
Armendáriz, M., Rosales, I., Bádenas, B., Aurell, M., GarcíaRamos, J.C., Pińuela, L., 2012. High-resolution chemostratigraphic records from Lower Pliensbachian belemnites: Palaeoclimatic perturbations, organic facies and water mass exchange (Asturian basin, northern Spain). Palaeogeography, Palaeoclimatology, Palaeoecology, 333-334: 178-191.

Bailey, T.R., Rosenthal, Y., McArthur, J.M., van de Schootbrugge, B., Thirwall, M.F., 2003. Paleoceanographic changes of the Late Pliensbachian-Early Toarcian interval: a possible link to the genesis of an Oceanic Anoxic Event. Earth and Planetary Science Letters, 212: 307-320.

Banner, J.L., 1995. Application of the trace element and isotope geochemistry of strontium to studies of carbonate diagenesis. Sedimentology, 42: 805-824.

Banner, J.L., Hanson, G.N., 1990. Calculation of simultaneous isotopic and trace element variations during water-rock interaction 
with applications to carbonate diagenesis. Geochimica et Cosmochimica Acta, 54: 3123-3137.

Banner, J.L., Kaufman, J., 1994. The isotopic record of ocean chemistry and diagenesis preserved in non-luminescent brachiopods from Mississippian carbonate rocks, Illinois and Missouri. GSA Bulletin, 106: 1074-1082.

Barbin, V., 2000. Cathodoluminescence of carbonate shells: biochemical vs diagenetic process. In: Cathodoluminescence in Geosciences (eds. M. Pagel, V. Barbin, P. Blanc and D. Ohnenstetter): 303-329. Springer, Berlin.

Barnaby, R.J., Rimstidt, J.D., 1989. Redox conditions of calcite cementation interpreted from $\mathrm{Mn}$ and Fe contents of authigenic calcites. GSA Bulletin, 101: 795-804.

Benito, M.I., Reolid, M., 2012. Belemnite taphonomy (Upper Jurassic, Western Tethys) part II: Fossil-diagenetic analysis including combined petrographic and geochemical techniques. Palaeogeography, Palaeoclimatology, Palaeoecology, 358-360: 89-108.

Blättler, C.L., Henderson, G.M., Jenkyns, H.C., 2012. Explaining the Phanerozoic Ca isotope history of seawater. Geology, 40: 843-846.

Bowen, R., 1961a. Oxygen isotope paleotemperature measurements on Cretaceous Belemnoidea from Europe, India and Japan. Journal of Paleontology, 35: 1077-1084.

Bowen, R., 1961b. Paleotemperature analyses of Mesozoic Belemnoidea from Australia and New Guinea. GSA Bulletin, 72: 769-774.

Brand, U., 1989. Biogeochemistry of Late Paleozoic North American brachiopods and secular variation of seawater composition. Biogeochemistry, 7: 159-193.

Brand, U., 1991. Strontium isotope diagenesis of biogenic aragonite and low-Mg calcite. Geochimica et Cosmochimica Acta, 55: 505-513.

Brand, U., 2004. Carbon, oxygen and strontium isotopes in Paleozoic carbonate components: an evaluation of original seawater-chemistry proxies. Chemical Geology, 204: 23-44.

Brand, U., Veizer, J., 1980. Chemical diagenesis of a multicomponent carbonate system-1: trace elements. Journal of Sedimentary Petrology, 50: 1219-1236.

Brand, U., Veizer, J., 1981. Chemical diagenesis of a multicomponent carbonate system-2: stable isotopes. Journal of Sedimentary Research, 51: 987-997.

Brand, U., Logan, A., Hiller, N., Richardson, J., 2003. Geochemistry of modern brachiopods: applications and implications for oceanography and paleoceanography. Chemical Geology, 198: 305-334.

Brand, U., Webster, G.D., Azmy, K., Logan, A., 2007. Bathymetry and productivity of the southern Great Basin seaway, Nevada, USA: an evaluation of isotope and trace element chemistry in mid-Carboniferous and modern brachiopods. Palaeogeography, Palaeoclimatology, Palaeoecology, 256: 273-297.

Bruckschen, P., Veizer, J., 1997. Oxygen and carbon isotopic composition of Dinantian brachiopods: paleoenvironmental implications for the Lower Carboniferous of western Europe. Palaeogeography, Palaeoclimatology, Palaeoecology, 132: 243-264.

Bruckschen, P., Oesmann, S., Veizer, J., 1999. Isotope stratigraphy of the European Carboniferous: proxy signals for ocean chemistry, climate and tectonics. Chemical Geology, 161: 127-163.

Buchardt, B., 1978. Oxygen isotope palaeotemperatures from the Tertiary period in the North Sea area. Nature, 275: 121-123.

Busenberg, E., Plummer, L.N., 1989. Thermodynamics of magnesian calcite solid-solutions at $25^{\circ} \mathrm{C}$ and $1 \mathrm{~atm}$ total pressure. Geochimica et Cosmochimica Acta, 53: 1189-1208.

Carpenter, S.J., Lohmann, K.C., 1992. Sr/Mg ratios of modern marine calcite: empirical indicators of ocean chemistry and precipitation rate. Geochimica et Cosmochimica Acta, 56: 1837-1849.

Carpenter, S.J., Lohmann, K.C., Holden, P., Walter, L.M., Huston, T.J., Halliday, A.N., 1991. $\delta^{18} \mathrm{O}$ values, ${ }^{87} \mathrm{Sr} /{ }^{86} \mathrm{Sr}$ and $\mathrm{Sr} / \mathrm{Mg}$ ratios of Late Devonian abiotic marine calcite: implications for the composition of ancient seawater. Geochimica et Cosmochimica Acta, 55: 1991-2010.

Cochran, J.K., Kallenberg, K., Landman, N.H., Harries, P.J., Weinreb, D., Turekian, K.K., Beck, A.J., Cobban, W.A., 2010.
Effect of diagenesis on $\mathrm{Sr}, \mathrm{O}$, and $\mathrm{C}$ isotope composition of late Cretaceous mollusks from the Western Interior Seaway of North America. American Journal of Science, 310: 69-88.

Coleman, M.L., Walsh, J.N., Benmore, R.A., 1989. Determination of both chemical and stable isotope composition in milligramme-size carbonate samples. Sedimentary Geology, 65: 233-238.

Compston, W., 1960. The carbon isotopic compositions of certain marine invertebrates and coals from the Australian Permian. Geochimica et Cosmochimica Acta, 18: 1-22.

Craig, H., 1954. Carbon 13 in plants and the relationships between carbon 13 and carbon 14 variations in nature. The Journal of $\mathrm{Ge}-$ ology, 62: 115-149.

Craig, H., 1957. Isotopic standards for carbon and oxygen and correction factors for mass-spectrometric analysis of carbon dioxide. Geochimica et Cosmochimica Acta, 12: 133-149.

Crerar, D.A., Barnes, H.L., 1974. Deposition of deep-sea manganese nodules. Geochimica et Cosmochimica Acta, 38: 279-300.

Cusack, M., Freer, A., 2008. Biomineralization: elemental and organic influence in carbonate systems. Chemical Reviews, 108: 4433-4454.

Dennis, K.J., Schrag, D.P., 2010. Clumped isotope thermometry of carbonatites as an indicator of diagenetic alteration. Geochimica et Cosmochimica Acta, 74: 4110-4122.

DePaolo, D.J., 2011. Surface kinetic model for isotopic and trace element fractionation during precipitation of calcite from aqueous solutions. Geochimica et Cosmochimica Acta, 75: 1039-1056.

Dickson, J.A.D., 1966. Carbonate identification and genesis as revealed by staining. Journal of Sedimentary Petrology, 36: 491-505.

Dickson, J.A.D., Coleman, M.L., 1980. Changes in carbon and oxygen isotope composition during limestone diagenesis. Sedimentology, 27: 107-118.

Dromgoole, E.L., Walter, L.M., 1990. Iron and manganese incorporation into calcite: effects of growth kinetics, temperature and solution chemistry. Chemical Geology, 81: 311-336.

Dutton, A., Huber, B.T., Lohmann, K.C., Zinsmeister, W.J., 2007. High-resolution stable isotope profiles of a dimitobelid belemnite: implications for paleodepth habitat and late Maastrichtian climate seasonality. Palaios, 22: 642-650.

Eidvin, T., Ullmann, C.V., Dybkjær, K., Rasmussen, E.S., Piasecki, S., 2014. Discrepancy between $\mathrm{Sr}$ isotope and biostratigraphic datings of the upper middle and upper Miocene successions (Eastern North Sea Basin, Denmark). Palaeogeography, Palaeoclimatology, Palaeoecology, 411: 267-280.

Eiler, J.M., 2007. "Clumped-isotope" geochemistry - the study of naturally-occuring, multiply-substituted isotopologues. Earth and Planetary Science Letters, 262: 309-327.

Eiler, J.M., 2011. Paleoclimatic reconstruction using carbonate clumped isotope thermometry. Quaternary Science Reviews, 30: 3575-3588.

Elderfield, H., 1986. Strontium isotope stratigraphy. Palaeogeography, Palaeoclimatology, Palaeoecology, 57: 71-90.

Emrich, K., Ehhalt, D.H., Vogel, J.C., 1970. Carbon isotope fractionation during the precipitation of calcium carbonate. Earth and Planetary Science Letters, 8: 363-371.

Epstein, S., Buchsbaum, R., Lowenstam, H., Urey, H.C., 1951. Carbonate-water isotopic temperature scale. GSA Bulletin, 62: 417-426.

Epstein, S., Buchsbaum, R., Lowenstam, H., Urey, H.C., 1953. Revised carbonate-water isotopic temperature scale. GSA Bulletin, 64: 1315-1326.

Fantle, M.S., Maher, K.M., DePaolo, D.J., 2010. Isotopic approaches for quantifying the rates of marine burial diagenesis. Reviews of Geophysics, 48: RG3002.

Finnegan, S., Bergmann, K., Eiler, J.M., Jones, D.S., Fike, D.A., Eisenman, I., Hughes, N.C., Tripati, A.K., Fischer, W.W., 2011. The magnitude and duration of Late Ordovician-Early Silurian glaciation. Science, 331: 903-906.

Frank, J.R., Carpenter, A.B., Oglesby, T.W., 1982. Cathodoluminescence and composition of calcite cement in the Taum Sauk Limestone (Upper Cambrian), Southeast Missouri. Journal of Sedimentary Petrology, 52: 631-638. 
Frei, R., Gaucher, C., Døssing, L.N., Sial, A.N., 2013. Chromium isotopes in carbonates - a tracer for climate change and for reconstructing the redox state of ancient seawater. Earth and Planetary Science Letters, 312: 114-125.

Freitas, P.S., Clarke, L.J., Kennedy, H., Richardson, C.A., Abrantes, F., 2006. Environmental and biological controls on elemental $(\mathrm{Mg} / \mathrm{Ca}, \mathrm{Sr} / \mathrm{Ca}$ and $\mathrm{Mn} / \mathrm{Ca})$ ratios in shells of the king scallop Pecten maximus. Geochimica et Cosmochimica Acta, 70: $5119-5133$

Freitas, P.S., Clarke, L.J., Kennedy, H., Richardson, C.A., 2009 Ion microprobe assessment of the heterogeneity of $\mathrm{Mg} / \mathrm{Ca}$, $\mathrm{Sr} / \mathrm{Ca}$ and $\mathrm{Mn} / \mathrm{Ca}$ ratios in Pecten maximus and Mytilus edulis (bivalvia) shell calcite precipitated at constant temperature. Biogeosciences, 6: 1209-1227.

Fritz, P., 1964. $\mathrm{O}^{18} / \mathrm{O}^{16}$-Isotopenanalysen und Paläotemperaturbestimmungen an Belemniten aus dem Schwäb. Jura. Geologische Rundschau, 54: 261-269.

Furuhashi, T., Schwarzinger, C., Miksik, I., Smrz, M., Beran, A., 2009. Molluscan shell evolution with review of shell calcification hypothesis. Comparative Biochemistry and Physiology, B 154: 351-371.

Gill, B.C., Lyons, T.W., Frank, T.D., 2008. Behaviour of carbonate-associated sulfate during meteoric diagenesis and implications for the sulfur isotope paleoproxy. Geochimica et Cosmochimica Acta, 72: 4699-4711.

Gill, B.C., Lyons, T.W., Jenkyns, H.C., 2011. A global perturbation to the sulfur cycle during the Toarcian Oceanic Anoxic Event. Earth and Planetary Science Letters, 312: 484-496.

Glasby, G.P., Schulz, H.D., 1999. Eh, pH diagrams for Mn, Fe, Co, $\mathrm{Ni}, \mathrm{Cu}$ and $\mathrm{As}$ under seawater conditions: applications of two new types of $\mathrm{Eh}, \mathrm{pH}$ diagrams to the study of specific problems in marine geochemistry. Aquatic Geochemistry, 5: 227-248.

Grossman, E.L., 2012. Applying oxygen isotope paleothermometry in deep time. The Paleontological Society Papers, 18: 39-67.

Grossman, E.L., Mii, H-S., Yancey, T.E., 1993. Stable isotopes in Late Pennsylvanian brachiopods from the United States: implications for Carboniferous paleoceanography. GSA Bulletin, 105: $1284-1296$

Grossman, E.L., Mii, H.-S., Zhang, C., Yancey, T.E., 1996. Chemical variation in Pennsylvanian brachiopod shells-diagenetic, taxonomic, microstructural, and seasonal effects. Journal of Sedimentary Research, 66: 1011-1022.

Henkes, G.A., Passey, B.J., Grossman, E.L., Shenton, B.J., Pérez-Huerta, A., Yancey, T.E., 2014. Temperature limits for preservation of primary calcite clumped isotope paleotemperatures. Geochimica et Cosmochimica Acta, 139: 362-382.

Hermoso, M., Minoletti, F., Rickaby, R.E.M., Hesselbo, S.P., Baudin, F., Jenkyns, H.C., 2012. Dynamics of a stepped carbon-isotope excursion: ultra high-resolution study of Early Toarcian environmental change. Earth and Planetary Science Letters, 319-320: 45-54.

Howarth, R.J., McArthur, J.M., 1997. Statistics for strontium isotope stratigraphy: a robust LOWESS fit to the marine Sr-isotope curve for 0 to $206 \mathrm{Ma}$, with look-up table for derivation of numeric age. Journal of Geology, 105: 441-456.

Immenhauser, A., Nägler, T.F., Steuber, T., Hippler, D., 2005. A critical assessment of mollusk ${ }^{18} \mathrm{O} /{ }^{16} \mathrm{O}, \mathrm{Mg} / \mathrm{Ca}$, and ${ }^{44} \mathrm{Ca} /{ }^{40} \mathrm{Ca}$ ratios as proxies for Cretaceous seawater temperature seasonality. Palaeogeography, Palaeoclimatology, Palaeoecology, 215: 215-237.

Jelby, M.E., Thibault, N., Surlyk, F., Ullmann, C.V., Harlou, R., Korte, C., 2014. The lower Maastrichtian Hvidskud succession, Møns Klint, Denmark: calcareous nannofossil biostratigraphy, carbon isotope stratigraphy, and bulk and brachiopod oxygen isotopes. Bulletin of the Geological Society of Denmark, 62: 89-104.

Jones, C.E., Jenkyns, H.C., Hesselbo, S.P., 1994. Strontium isotopes in Early Jurassic seawater. Geochimica et Cosmochimica Acta, 58: 1285-1301.

Jordan, R., Stahl, W., 1970. Isotopische PaläotemperaturBestimmungen an jurassischen Ammoniten und grundsätzliche
Voraussetzungen für diese Methode. Geologisches Jahrbuch, 89: 33-62.

Korte, C., Hesselbo, S.P., 2011. Shallow marine carbon and oxygen isotope and elemental records indicate icehouse-greenhouse cycles during the Early Jurassic. Paleoceanography, 26: PA4219.

Korte, C., Kozur, H.W., Bruckschen, P., Veizer, J., 2003. Strontium isotope evolution of Late Permian and Triassic seawater. Geochimica et Cosmochimica Acta, 67: 47-62.

Korte, C., Kozur, H.W., Veizer, J., 2005a. $\delta^{18} \mathrm{O}$ and $\delta^{13} \mathrm{C}$ of Triassic brachiopods and carbonate rocks as proxies for coeval seawater and Palaeotemperature. Palaeogeography, Palaeoclimatology, Palaeoecology, 226: 287-306.

Korte, C., Jasper, T., Kozur, H.W., Veizer, J., 2005b. $\delta^{18} \mathrm{O}$ and $\delta^{13} \mathrm{C}$ of Permian brachiopods: a record of seawater evolution and continental glaciation. Palaeogeography, Palaeoclimatology, Palaeoecology, 224: 333-351.

Korte, C., Jasper, T., Kozur, H.W., Veizer, J., 2006. ${ }^{87} \mathrm{Sr} /{ }^{86} \mathrm{Sr}$ record of Permian seawater. Palaeogeography, Palaeoclimatology, Palaeoecology, 240: 89-107.

Korte, C., Jones, P., Brand, U., Mertmann, D., Veizer, J., 2008 Oxygen isotope values from high-latitudes: Clues for Permian sea-surface temperature gradients and Late Palaeozoic deglaciation. Palaeogeography, Palaeoclimatology, Palaeoecology, 269: $1-16$

Korte, C., Hesselbo, S.P., Jenkyns, H.C., Rickaby, R.E.M., Spötl, C., 2009. Palaeoenvironmental significance of carbon- and oxygen-isotope stratigraphy of marine Triassic-Jurassic boundary sections in SW Britain. Journal of the Geological Society, 166: 431-445.

Li, Q., McArthur, J.M., Atkinson, T.C., 2012. Lower Jurassic belemnites as indicators of palaeo-temperature. Palaeogeography, Palaeoclimatology, Palaeoecology, 315-316: 38-45.

Longinelli, A., 1969. Oxygen-18 variations in belemnite guards. Earth and Planetary Science Letters, 7: 209-212.

Lorens, R.B., 1981. Sr, Cd, Mn and Co distribution coefficients in calcite as a function of calcite precipitation rate. Geochimica et Cosmochimica Acta, 45: 553-561.

Lu, F.H., 2008. Pristine or altered: low-Mg calcite shells survived from massive dolomitization? A case study from Miocene carbonates. Geo-Marine Letters, 28: 339-349.

Machel, H.G., 1985. Cathodoluminescence in calcite and dolomite and its chemical interpretation. Geoscience Canada, 12: 139-147.

Machel, H.G., Burton, E.A., 1991. Factors governing cathodoluminescence in calcite and dolomite and their implications for studies of carbonate diagenesis. SEPM Short Course, 25: 37-57.

Malkoc, M., Mutterlose, J., 2010. The early Barremian warm pulse and the late Barremian cooling: a high-resolution geochemical record of the Boreal Realm. Palaios, 25: 14-23.

Major, R.P., Wilber, R.J., 1991. Crystal habit, geochemistry, and cathodoluminescence of magnesian calcite marine cements from the lower slope of Little Bahama Bank. GSA Bulletin, 103: 461-471.

Marshall, J.D., 1992. Climatic and oceanographic isotopic signals from the carbonate rock record and their preservation. Geological Magazine, 129: 143-160

McArthur, J.M., Donovan, D.T., Thirwall, M.F., Fouke, B.W., Mattey, D., 2000. Strontium isotope profile of the early Tiarcian (Jurassic) oceanic anoxic event, the duration of ammonite biozones, and belemnite palaeotemperatures. Earth and Planetary Science Letters, 179: 269-285.

McArthur, J.M., Howarth, R.J., Bailey, T.R., 2001. Strontium Isotope Stratigraphy: LOWESS Version 3: best fit to the marine Sr-isotope curve for 0-509 $\mathrm{Ma}$ and accompanying look-up table for deriving numerical age. Journal of Geology, 109: 155-170.

McArthur, J.M., Doyle, P., Leng, M.J., Reeves, K., Williams, C.T., Garcia-Sanchez, R., Howarth, R.J., 2007. Testing palaeo-environmental proxies in Jurassic belemnites: $\mathrm{Mg} / \mathrm{Ca}, \mathrm{Sr} / \mathrm{Ca}, \mathrm{Na} / \mathrm{Ca}$, $\delta^{18} \mathrm{O}$ and $\delta^{13} \mathrm{C}$. Palaeogeography, Palaeoclimatology, Palaeoecology, 252: $464-480$ 
Mette, W., Elsler, A., Korte, C., 2012. Palaeoenvironmental changes in the Late Triassic (Rhaetian) of the Northern Calcareous Alps: Clues from stable isotopes and microfossils. Palaeogeography, Palaeoclimatology, Palaeoecology, 350-352: 62-72.

Mii, H.-S., Grossman, E.L., Yancey, T.E., 1997. Stable carbon and oxygen isotope shifts in Permian seas of west Spitsbergen Global change or diagenetic artifact? Geology, 25: 227-230.

Mii, H.-S., Grossman, E.L., Yancey, T.E., 1999. Carboniferous isotope stratigraphies of North America: implications for Carboniferous paleoceanography and Mississippian glaciation. GSA Bulletin, 111: 960-973.

Misra, S., Froelich, P.N., 2012. Lithium isotope history of Cenozoic seawater: changes in silicate weathering and reverse weathering. Science, 335: 818-823.

Morrison, J.O., Brand, U., 1986. Paleoscene \#5. Geochemistry of recent marine invertebrates. Geoscience Canada, 13: 237-254.

Mutterlose, J., Malkoc, M., Schouten, S., Sinninghe Damsté, J.S., Forster, A., 2010. $\mathrm{TEX}_{86}$ and stable $\delta^{18} \mathrm{O}$ paleothermometry of early Cretaceous sediments: implications for belemnite ecology and paleotemperature proxy application. Earth and Planetary Science Letters, 298: 286-298.

Nier, A.O., 1938. The isotopic constitution of strontium, barium, bismuth, thallium and mercury. Physical Review, 5: 275-278.

Nunn, E.V., Price, G.D., 2010. Late Jurassic (KimmeridgianTithonian) stable isotopes $\left(\delta^{18} \mathrm{O}, \delta^{13} \mathrm{C}\right)$ and $\mathrm{Mg} / \mathrm{Ca}$ ratios: new palaeoclimate data from Helmsdale, northeast Scotland. Palaeogeography, Palaeoclimatology, Palaeoecology, 292: 325-335.

Okumura, M., Kitano, Y., 1986. Coprecipitation of alkali metal ions with calcium carbonate. Geochimica et Cosmochimica Acta, 50: 49-58.

O’Neil, J.R., Clayton, R.N., Mayeda, T.K., 1969. Oxygen isotope fractionation in divalent metal carbonates. The Journal of Chemical Physics, 51: 5547-5558.

Parkinson, D., Curry, G.B., Cusack, M., Fallick, A.E., 2005. Shell structure, patterns and trends of oxygen and carbon stable isotopes in modern brachiopod shells. Chemical Geology, 219: 193-235.

Pérez-Huerta, A., Cusack, M., 2009. Optimizing electron backscatter diffraction of carbonate biominerals - resin type and carbon coating. Microscopy and Microanalysis, 15: 197-203.

Plummer, L.N., Busenberg, E., 1982. The solubilities of calcite, aragonite and vaterite in $\mathrm{CO}_{2}-\mathrm{H}_{2} \mathrm{O}$ solutions between 0 and $90^{\circ} \mathrm{C}$, and an evaluation of the aqueous model for the system $\mathrm{CaCO}_{3}$ $\mathrm{CO}_{2}-\mathrm{H}_{2} \mathrm{O}$. Geochimica et Cosmochimica Acta, 46: 1011-1040.

Podlaha, O.G., Mutterlose, J., Veizer, J., 1998. Preservation of $\delta^{18} \mathrm{O}$ and $\delta^{13} \mathrm{C}$ in belemnite rostra from the Jurassic/early Cretaceous successions. American Journal of Science, 298: 324-347.

Pokroy, B., Fitch, A.N., Marin, F., Kapon, M., Adir, N., Zolotoyabko, E., 2006. Anisotopric lattice distortions in biogenic calcite induced by intra-crystalline organic molecules. Journal of Structural Biology, 155: 96-103.

Popp, B.N., Anderson, T.F., Sandberg, P.A., 1986. Brachiopods as indicators of original isotopic compositions in some Paleozoic limestones. GSA Bulletin, 97: 1262-1269.

Price, G.D., Mutterlose, J., 2004. Isotopic signals from late Jurassic-early Cretaceous (Volgian-Valanginian) sub-Arctic belemnites, Yatria River, Western Siberia. Journal of the Geological Society, 161: 959-968.

Price, G.D., Rogov, M.A., 2009. An isotopic appraisal of the Late Jurassic greenhouse phase in the Russian Platform. Palaeogeography, Palaeoclimatology, Palaeoecology, 273: 41-49.

Price, G.D., Sellwood, B.W., 1997. "Warm" palaeotemperatures from high Late Jurassic palaeolatitudes (Falkland Plateau): ecological, environmental or diagenetic controls? Palaeogeography, Palaeoclimatology, Palaeoecology, 129: 315-327.

Price, G.D., Passey, B.H., 2013. Dynamic polar climates in a greenhouse world; evidence from clumped isotope thermometry of Early Cretaceous belemnites. Geology, 41: 923-926.

Price, G.D., Fözy, I., Janssen, N.M.M., Pálfy, J., 2011. Late Valanginian-Barremian (Early Cretaceous) palaeotemperatures inferred from belemnite stable isotope and $\mathrm{Mg} / \mathrm{Ca}$ ratios from Bersek Quarry (Gerecse Mountains, Transdanubian Range,
Hungary). Palaeogeography, Palaeoclimatology, Palaeoecology, 305: 1-9.

Price, G.D., Twitchett, R.J., Wheeley, J.R., Buono, G., 2013. Isotopic evidence for long term warmth in the Mesozoic. Scientific Reports, 3: 1438, doi: 10.1038/srep01438

Prokoph, A., Shields, G.A., Veizer, J., 2008. Compilation and time-series analysis of a marine carbonate $\delta^{18} \mathrm{O}, \delta^{13} \mathrm{C},{ }^{87} \mathrm{Sr} /{ }^{86} \mathrm{Sr}$ and $\delta^{34} S$ database through Earth history. Earth-Science Reviews, 87: 113-133.

Ray, J.S., Veizer, J., Davis, W.J., 2003. C, O, Sr and Pb isotope systematics of carbonate sequences of the Vindhyan Supergroup, India: age, diagenesis, correlations and implications for global events. Precambrian Research, 121: 103-140.

Rimstidt, J.D., Balog, A., Webb, J., 1998. Distribution of trace elements between carbonate minerals and aqueous solutions. Geochimica et Cosmochimica Acta, 62: 1851-1863.

Rosales, I., Quesada, S., Robles, S., 2001. Primary and diagenetic isotopic signals in fossils and hemipelagic carbonates: the Lower Jurassic of northern Spain. Sedimentology, 48: 1149-1169.

Rosales, I., Quesada, S., Robles, S., 2004. Paleotemperature variations of Early Jurassic seawater recorded in geochemical trends of belemnites from the Basque-Cantabrian basin, northern Spain. Palaeogeography, Palaeoclimatology, Palaeoecology, 203: 253-275.

Rush, P.F., Chafetz, H.S., 1990. Fabric-retentive, non-luminescent brachiopods as indicators of original $\delta^{13} \mathrm{C}$ and $\delta^{18} \mathrm{O}$ composition: a test. Journal of Sedimentary Petrology, 60: 968-981.

Saenger, C., Wang, Z., 2014. Magnesium isotope fractionation in biogenic and abiogenic carbonates: implications for paleoenvironmental proxies. Quaternary Science Reviews, 90: 1-21.

Sample, J.C., Reid, M.R., 1998. Contrasting hydrogeologic regimes along strike-slip and thrust faults in the Oregon convergent margin: evidence from the chemistry of syntectonic carbonate cements and veins. GSA Bulletin, 110: 48-59.

Savard, M.M., Veizer, J., Hinton, R., 1995. Cathodoluminescence at low Fe and Mn concentrations; a SIMS study of zones in natural calcites. Journal of Sedimentary Research, 65: 208-213.

Schobben, M., Joachimski, M.M., Korn, D., Leda, L., Korte, C., 2014. Palaeotethys seawater temperature rise and an intensified hydrological cycle following the end-Permian mass extinction. Gondwana Research, 26: 675-683.

Sharp, Z., 2007. Principles of Stable Isotope Geochemistry. Pearson Prentice Hall, New Jersey.

Shaviv, N.J., Prokoph, A., Veizer, J., 2014. Is the solar system's galactic motion imprinted in the Phanerozoic climate? Scientific Reports, 4: 6150, doi: 10.1038/srep06150

Shen, C.-C., Hastings, D.W., Lee, T., Chiu, C.-H., Lee, M.-Y., Wei, K.-Y., Edwards, R.L., 2001. High precision glacial-interglacial benthic foraminiferal $\mathrm{Sr} / \mathrm{Ca}$ records from the eastern equatorial Atlantic Ocean and Caribbean Sea. Earth and Planetary Science Letters, 190: 197-209.

Shields, G.A., Carden, G.A.F., Veizer, J., Meidla, T., Rong, J.-Y., Li, R.-Y., 2003. Sr, C, and O isotope geochemistry of Ordovician brachiopods: a major isotopic event around the Middle-Late Ordovician transition. Geochimica et Cosmochimica Acta, 67: 2005-2025.

Stahl, W., Jordan, R., 1969. General considerations on isotopic paleotemperature determinations and analyses on Jurassic ammonites. Earth and Planetary Science Letters, 6: 173-178.

Steuber, T., Veizer, J., 2002. Phanerozoic record of plate tectonic control of seawater chemistry and carbonate sedimentation. Geology, 30: 1123-1126.

Steuber, T., Buhl, D., 2006. Calcium-isotope fractionation in selected modern and ancient marine carbonates. Geochimica et Cosmochimica Acta, 70: 5507-5521.

Steuber, T., Rauch, M., Masse, J.-P., Graaf, J., Malkoč, M., 2005. Low-latitude seasonality of Cretaceous temperatures in warm and cold episodes. Nature, 437: 1341-1344.

Sælen, G., 1989. Diagenesis and construction of the belemnite rostrum. Palaeontology, 32: 765-798.

Sælen, G., Doyle, P., Talbot, M.R., 1996. Stable-isotope analyses of belemnite rostra from the Whitby Mudstone Fm., England: 
surface water conditions during deposition of a marine black shale. Palaios, 11: 97-117.

Tan, F.C., Hudson, J.D., 1974. Isotopic studies on the palaeoecology and diagenesis of the Great Estuarine Series (Jurassic) of Scotland. Scottish Journal of Geology, 10: 97-128.

Tan, F.C., Hudson, J.D., Keith, M.L., 1970. Jurassic (Callovian) Paleotemperatures from Scotland. Earth and Planetary Science Letters, 9: 421-426.

Tang, J., Köhler, S.J., Dietzel, M., 2008. $\mathrm{Sr}^{2+} / \mathrm{Ca}^{2+}$ and ${ }^{44} \mathrm{Ca} /{ }^{40} \mathrm{Ca}$ fractionation during inorganic calcite formation: I. Sr incorporation. Geochimica et Cosmochimica Acta, 72: 3718-3732.

Thomson, J., Higgs, N.C., Jarvis, I., Hydes, D.J., Colley, S., Wilson, T.R.S., 1986. The behaviour of manganese in Atlantic carbonate sediments. Geochimica et Cosmochimica Acta, 50: 1807-1818.

Ullmann, C.V., Wiechert, U., Korte, C., 2010. Oxygen isotope fluctuations in a modern North Sea oyster (Crassostrea gigas) compared with annual variations in seawater temperature: implications for palaeoclimate studies. Chemical Geology, 277: 160-166.

Ullmann, C.V., Campbell, H.J., Frei, R., Hesselbo, S.P., Pogge von Strandmann, P.A.E., Korte, C., 2013a. Partial diagenetic overprint of Late Jurassic belemnites from New Zealand: implications for the preservation potential of $\delta^{7} \mathrm{Li}$ values in calcite fossils. Geochimica et Cosmochimica Acta, 120: 80-96.

Ullmann, C.V., Böhm, F., Rickaby, R.E.M., Wiechert, U., Korte, C., 2013b. The Giant Pacific Oyster (Crassostrea gigas) as a modern analog for fossil ostreoids: isotopic $(\mathrm{Ca}, \mathrm{O}, \mathrm{C})$ and elemental ( $\mathrm{Mg} / \mathrm{Ca}, \mathrm{Sr} / \mathrm{Ca}, \mathrm{Mn} / \mathrm{Ca}$ ) proxies. Geochemistry, Geophysics, Geosystems, 14: 4109-4120.

Ullmann, C.V., Hesselbo, S.P., Korte, C., 2013c. Tectonic forcing of Early to Middle Jurassic seawater $\mathrm{Sr} / \mathrm{Ca}$. Geology, 41: $1211-1214$

Ullmann, C.V., Thibault, N., Ruhl, M., Hesselbo, S.P., Korte, C., 2014a. Effect of a Jurassic Oceanic Anoxic Event on belemnite ecology and evolution. Proceedings of the National Academy of Science of the USA, 111: 10073-10076.

Ullmann, C.V., Campbell, H.J., Frei, R., Korte, C., 2014b. Geochemical signatures in Late Triassic brachiopods from New Caledonia. New Zealand Journal of Geology and Geophysics, 57: $420-431$.

Urey, H.C., 1947. The thermodynamic properties of isotopic substances. Journal of the Chemical Society, 562-582.

Urey, H.C., Lowenstam, H.A., Epstein, S., McKinney, C.R., 1951. Measurement of paleotemperatures and temperatures of the upper Cretaceous of England, Denmark, and the southeastern United States. GSA Bulletin, 62: 399-416.

Vander Putten, E., Dehairs, F., Keppens, E., Baeyens, W., 2000 High resolution distribution of trace elements in the calcite shells layer of modern Mytilus edulis: environmental and biological controls. Geochimica et Cosmochimica Acta, 64: 997-1011.

van de Schootbrugge, B., McArthur, J.M., Bailey, T.R., Rosenthal, Y., Wright, J.D., Miller, K.G., 2005. Toarcian oceanic anoxic event: an assessment of global causes using belemnite C isotope records. Paleoceanography, 20: PA3008.

Veizer, J., 1974. Chemical diagenesis of belemnite shells and possible consequences for paleotemperature determinations. Neues Jahrbuch für Geologie und Paläontologie Abhandlungen, 147: 91-111.

Veizer, J., 1983a. Chemical diagenesis of carbonates: theory and application of trace element technique. SEPM Short Course, 10: $3 / 1-3 / 100$

Veizer, J., 1983b. Trace elements and isotopes in sedimentary carbonates. Review in Mineralogy, 11: 265-299.

Veizer, J., Fritz, P., 1976. Possible control of post-depositional alteration in oxygen paleotemperature determinations. Earth and Planetary Science Letters, 33: 255-260.
Veizer, J., Fritz, P., Jones, B., 1986. Geochemistry of brachiopods oxygen and carbon isotopic records of Paleozoic oceans. Geochimica et Cosmochimica Acta, 50: 1679-1696.

Veizer, J., Ala, D., Azmy, K., Bruckschen, P., Buhl, D., Bruhn, F., Carden, G.A.F., Diener, A., Ebneth, S., Godderis, Y., Jasper, T., Korte, C., Pawellek, F., Podlaha, O.G., Strauss, H., 1999. ${ }^{87} \mathrm{Sr} /{ }^{86} \mathrm{Sr}, \delta^{13} \mathrm{C}$ and $\delta^{18} \mathrm{O}$ evolution of Phanerozoic seawater. Chemical Geology, 161: 59-88.

Voigt, J., Hathorne, E.C., Frank, M., Vollstaedt, H., Eisenhauer, A., 2015. Variability of carbonate diagenesis in equatorial Pacific sediments deduced from radiogenic and stable $\mathrm{Sr}$ isotopes. Geochimica et Cosmochimica Acta, 148: 360-377.

Voigt, S., Wilmsen, M., Mortimore, R.N., Voigt, T., 2003 Cenomanian palaeotemperatures derived from the oxygen isotopic composition of brachiopods and belemnites: evaluation of Cretaceous palaeotemperature proxies. International Journal of Earth Sciences, 92: 285-299.

Vollstaedt, H., Eisenhauer, A., Wallmann, K., Böhm, F., Fietzke, J., Liebetrau, V., Krabbenhöft, A., Farkaš, J., Tomašových, A., Raddatz, J., Veizer, J., 2014. The Phanerozoic $\delta^{88} /{ }^{86} \mathrm{Sr}$ record of seawater: new constraints on past changes in oceanic carbonate fluxes. Geochimica et Cosmochimica Acta, 128: 249-265.

Watkins, J.M., Nielsen, L.C., Ryerson, F.J., DePaolo, D.J., 2013 The influence of kinetics on the oxygen isotope composition of calcium carbonate. Earth and Planetary Science Letters, 375: 349-360.

Wefer, G., Berger, W.H., 1991. Isotope paleontology: growth and composition of extant - calcareous species. Marine Geology, 100: 207-248.

Weiner, S., Dove, P.M., 2003. An overview of biomineralization processes and the problem of the vital effect. Reviews in Mineralogy and Geochemistry, 54: 1-29.

Wierzbowski, H., 2013. Strontium isotope composition of sedimentary rocks and its application to chemostratigraphy and palaeoenvironmental reconstructions. Annales Universitatis Mariae Curie-Skłodowska Lublin-Polonia Sectio AAA, 68: 23-37.

Wierzbowski, H., Joachimski, M.M., 2007. Reconstruction of late Bajocian-Bathonian marine palaeoenvironments using carbon and oxygen isotope ratios of calcareous fossils from the Polish Jura Chain (central Poland). Palaeogeography, Palaeoclimatology, Palaeoecology, 254: 523-540.

Wierzbowski, H., Joachimski, M.M., 2009. Stable isotopes, elemental distribution, and growth rings of belemnopsid belemnite rostra: proxies for belemnite life habitat. Palaios, 24: 377-386.

Wierzbowski, H., Dembicz, K., Praszkier, T., 2009. Oxygen and carbon isotope composition of Callovian-Lower Oxfordian (Middle-Upper Jurassic) belemnite rostra from central Poland: a record of a Late Callovian global sea-level rise? Palaeogeography, Palaeoclimatology, Palaeoecology, 283: 182-194.

Wierzbowski, H., Anczkiewicz, R., Bazarnik, J., Pawlak, J., 2012. Strontium isotope variations in Middle Jurassic (late BajocianCallovian) seawater; implications for Earth's tectonic activity and marine environments. Chemical Geology, 334: 171-181.

Yamamoto, K., Asami, R., Iryu, Y., 2011. Brachiopod taxa and shell portions reliably recording past ocean environments: toward establishing a robust paleoceanographic proxy. Geophysical Research Letters, 38: L13601, doi: 10.1029/2011GL047134

Zeebe, R.E., 2007. An expression for the overall oxygen isotope fractionation between the sum of dissolved inorganic carbon and water. Geochemistry, Geophysics, Geosystems, 8: Q09002, doi: 10.1029/2007GC001663

Zhang, Z., 2009. Geochemical properties of shells of Arctica islandica (Bivalvia) - implications for environmental and climatic change. Upublished PhD thesis, Goethe-Universität Frankfurt am Main. 